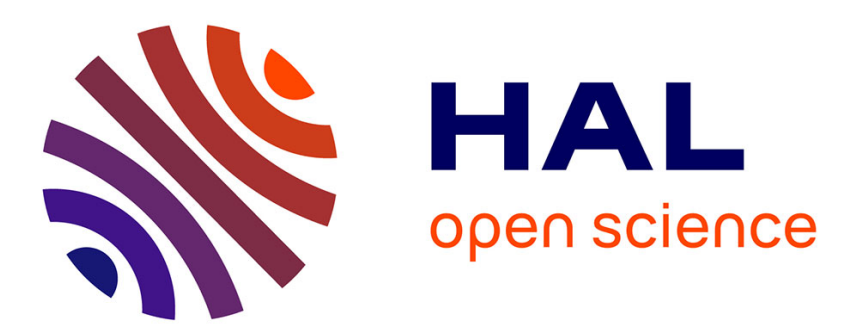

\title{
Organic additives for hydrotreating catalysts: a review of main families and action mechanisms
}

Laetitia Oliviero, Françoise Maugé, P. Afanasiev, Camila Pedraza Parra, C.

Geantet

\section{- To cite this version:}

Laetitia Oliviero, Françoise Maugé, P. Afanasiev, Camila Pedraza Parra, C. Geantet. Organic additives for hydrotreating catalysts: a review of main families and action mechanisms. Catalysis Today, 2021, 10.1016/j.cattod.2020.09.008 . hal-03082287

\section{HAL Id: hal-03082287 \\ https://hal.science/hal-03082287}

Submitted on 18 Dec 2020

HAL is a multi-disciplinary open access archive for the deposit and dissemination of scientific research documents, whether they are published or not. The documents may come from teaching and research institutions in France or abroad, or from public or private research centers.
L'archive ouverte pluridisciplinaire $\mathbf{H A L}$, est destinée au dépôt et à la diffusion de documents scientifiques de niveau recherche, publiés ou non, émanant des établissements d'enseignement et de recherche français ou étrangers, des laboratoires publics ou privés. 


\title{
Organic additives for hydrotreating catalysts: a review of main families and action mechanisms.
}

\author{
Laetitia Oliviero ${ }^{\mathrm{a},}{ }^{*}$, Francoise Maugé ${ }^{\mathrm{a}}$, Pavel Afanasiev ${ }^{\mathrm{b}}$, Camila Pedraza-Parra ${ }^{\mathrm{a}, \mathrm{b}}$, Christophe \\ Geantet $^{\mathrm{b}, *}$. \\ ${ }^{a}$ Normandie Univ., ENSICAEN, UNICAEN, CNRS, LCS, 14000 Caen, France

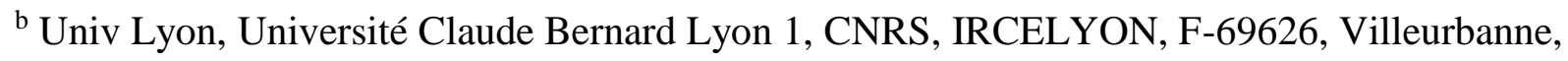 \\ France.
}

Corresponding authors: laetitia.oliviero@ensicaen.fr, Christophe.geantet@ircelyon.univlyon1.fr

Keywords: HDS and HDN catalysts; sulfides; chelating agents, thio and organic additives, catalyst preparation, regeneration.

\begin{abstract}
Ever more active hydrotreating (HDT) catalysts should be developed to meet the growing demand for cleaner fuels. With each novel generation of HDT catalysts the requirements of performance, stability and possibility of regeneration become more sophisticated. Versatile types of organic molecules are applied to improve the HDT catalysts, and to activate regenerated catalysts. The additives improve the dispersion of the active phase, the degree of promotion and modify the interactions with the support. Complex chemical and physical processes are involved in the mechanisms of action, which are different from one family of additives to another. In this review we summarize recent advances on the main types of additives, the current state of understanding of the mechanisms of their action as well as challenges and perspectives in developing novel additives for highly performing novel generations of HDT catalysts in a sustainable way.
\end{abstract}

\section{Introduction}

Whatever the scenario and pace of the future energy transition, fossil fuels in general and oil in particular will stay the main energy sources for several forthcoming decades. Hydrotreating 
(HDT) catalysts used to upgrade oil will remain therefore one of the most important families of catalysts on the market, both by volume and by price.

Activation of HDT catalysts by means of sulfidation of oxide precursors is an essential step in the preparation of the active species of supported $\mathrm{Co}(\mathrm{Ni})-\mathrm{Mo}(\mathrm{W}) \mathrm{S}_{2}$ sulfides. This step must be finely tuned as multiple interactions between the components in the oxide pre-catalyst may lead to the loss of active metals in the forms of individual low active sulfides (e.g. $\mathrm{Cog}_{9} \mathrm{~S}_{8}$ ) or species strongly interacting with the oxide support (e.g. $\left.\mathrm{CoAl}_{2} \mathrm{O}_{4}\right)$. Optimization of HDT catalysts can be achieved by means of introducing organic additives, often glycol-type compounds or chelating agents. These agents influence the kinetics of chemical processes during the activation step and positively impact the properties of the resulting sulfide. Comprehension of the role of the organic additives becomes necessary in particular with respect of the last generation of HDT catalysts, more active but more sensitive to the activation and regeneration conditions.

Organic additives interaction with HDT catalysts has been studied since the 80 's and the first industrial application concerned S- containing molecules. They were used to introduce on the catalysts a sulfidation compound which enables activation of the catalyst inside the refinery unit without requiring any further sulfur addition. So-called SULFICAT process used alkylpolysulfides for this purpose [1]. At the same period, non S-containing molecules such as chelating agents were investigated at the laboratory scale and patented as promoters introduced during the preparation of the catalyst in its oxidic form. Whatever the nature of molecules, organic additives can be divided in two families: the chelating additives allowing complexation with metallic ions and the non-chelating agents. But due to the particular role of sulfur in the genesis of sulfide catalysts, it seems preferable to also distinguish the organic compounds into two types: S-containing and non S-containing organic additives. More complex molecules such as saccharose or self- polymerizing dopamine were also recently investigated. Patents and academic studies evidence the so called "booster effect" of organic additives and the enhancement of catalytic activities may originate from many effects, some of them being clearly demonstrated and others still needing a better understanding. This article will attempt to review the origin and impacts of the various types of organic additives. 


\section{Sulfur-containing additives}

Addition of sulfur containing compounds, such as thioglycolic acid (TGA, Figure 1.a) and “alkylpolysulfides", in particular ditertiononyl pentasulfide (TNPS, Figure 1 b) have been used for ex situ sulfidation in order to obtain presulfided hydrodesulfurization (HDS) catalysts [2$4]$.

The usual activation procedures include impregnation of sulfur-containing molecules on an oxidic phase catalyst followed by hydrogen treatment at $100-350{ }^{\circ} \mathrm{C}$, usually under medium high pressure, 20-40 bar.

a)

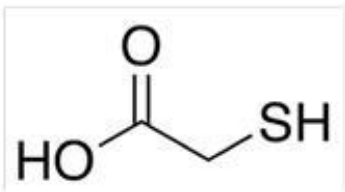

b)

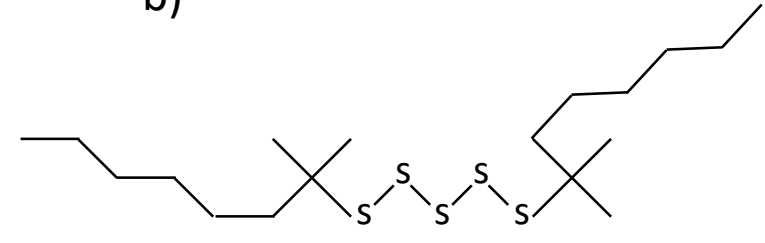

Figure 1: Typical sulfur-containing additives to HDS catalysts:

a) thioglycolic acid and b) ditertiononyl pentasulfide

If an analogy with the conventional additives described later on is relevant, thioglycolic acid corresponds to citric acid and other chelating agents such as Ethylene diamino tetra acetic acid (EDTA) and nitrilotriacetic acid (NTA). Indeed, TGA is acidic; it contains multiple functionalities and demonstrates formation of stable complexes with transition metals [5]. On the other side, long hydrophobic chains of TNPS might be compared to the long and lesser complexing chains of polyglycols. The step forward in the use of sulfur-bearing agents is in their double functionality, combining the known effects of non-sulfur-bearing organic additives (vide infra) with the sulfiding action power i.e. "two in one" action principle. Except the role in the O-S exchange during the heating treatment, the general mechanisms of action of sulfurbearing additives seem to be similar to those of the non-sulfur additives. They might include chemical, thermal and morphological effects, in versatile combinations. As any organics they require an energy input to be decomposed at moderate temperatures and therefore they are able to absorb excessive heat evolved in the sulfidation process. That would prevent excessive sintering of the active phase during the activation process (thermal effect). The formation of TGA complexes with transition metals if somehow lesser studied than in the case of EDTA or NTA, is still well documented (chemical effect). Finally, the S-bearing molecules decompose 
leaving residual carbon. The favorable role of carbon present in the active sulfide phase for the improvement of HDS properties of catalysts generated from organosulfur precursors was shown in several works [2],[3],[6]. The inclusion of $\mathrm{C}$ in the active phase in HDS was claimed by Chianelli et al.[7], who asserted that the carbon atoms replace sulfur on the sulfide edges. Even if this last statement has not been widely accepted by the community, the weaker statement is obviously true about the possible beneficial role of carbon on the properties of HDS systems due to stabilization of highly dispersed sulfide (morphological action). These mechanisms of action are not mutually excluding and might be manifested simultaneously, in a concerted way.

\subsection{Dialkyl polysulfides}

Industrial application of alkyl polysulfides preceded the efforts of academic understanding of their action. SULFICAT ${ }^{\circledR}$ process, the EURECAT patented off-site presulfiding process, has been developed in 1980 and tested in laboratories and pilot plants around the world with excellent results. Both fresh and regenerated catalyst have been presulfided and utilized in liquid and gas phase start-up procedures. The advantages as claimed by the inventors are the reduced time of start-up (from days to hours), minimized out of specification product and elimination of dangerous sulfur agents and their handling [8].

An oxidic catalyst pre-sulfided by the SULFICAT® process using alkylpolysulfide was studied by Labruyere et al. [3,4]. Comparison with the ex-situ sulfidation by $\mathrm{H}_{2} \mathrm{~S}$ showed that the SULFICAT® process affords a higher HDS activity, related to higher dispersion of the sulfided active phase. XPS revealed strong interaction of the alkylpolysulfide with the catalyst that leads to a partial reduction of molybdenum ions after the drying step. Under hydrogen, the polysulfide decomposed at $160-220^{\circ} \mathrm{C}$ converting the initial oxide $\mathrm{Mo}(\mathrm{VI})$ species into $\mathrm{MoS}_{2}$. The sulfidation state of the active phase and its dispersion increase with the hydrogen pressure [3]'[4].

The organic sulfur compound bis-(1,1,3,3-tetramethylbutyl)-polysulfide was investigated as a novel sulfiding agent by Kabe et al.[9]'[10]. A commercial $\mathrm{CoMo} / \mathrm{Al}_{2} \mathrm{O}_{3}$ catalyst was sulfided with different agents and the activity was compared in HDS of DBT. The catalyst presulfided using the polysulfide showed the same or higher activity vs those using the conventional sulfiding agents dimethyl disulfide (DMDS) and $\mathrm{CS}_{2}$. The catalytic activity for HDS and hydrogenation depended remarkably on the presulfiding procedure such as type of sulfiding agent, temperature program in the presulfiding procedure, and in situ or ex situ 
method. The $\mathrm{S}^{35}$ radioisotope tracer method was used to elucidate the effect of sulfiding parameters on sulfur behavior of the sulfided catalyst during the HDS reaction. The effects of sulfiding agent on the catalytic activity were supposed to mainly originate from the differences in the amount of labile sulfur formed in the different sulfiding processes.

The effects of organosulfur sulfiding molecule and of the solvent were analyzed by Texier et al. [11]. The authors concluded that if the sulfiding agents are used under rigorously identical conditions, there is no significant difference in the HDS performance of the obtained catalysts. The actual beneficial effect of organosulfides as activating agents as observed in the industrial practice was attributed not to their chemical effect but to the "thermal well" effect. The organosulfides were supposed to absorb the heat evolved in the exothermic oxide-sulfide transformation and better dispersion of the obtained sulfides explained the better efficiency of organosulfides as sulfiding agents.

In fact, having somewhat different reactivity and larger carbon chains, polysulfides are close by their chemical nature to DMDS. The latter is usually considered merely as a sulfidation agent and not as an "organic additive". By the same token, polysulfides might be regarded at the first place as sulfidation agents. In contrast to TGA such molecules do not impact directly the oxide precursor on the impregnation steps, but interfere later, during the chemical reaction at increased temperature.

Overall, the literature analysis shows that sulfur-bearing additives may lead to highly active HDS systems. The main interest of these sulfur-containing additives lies in the possibility to activate catalysts without the use of $\mathrm{H}_{2} \mathrm{~S}$ (ex situ) or of DMDS (in situ) but to apply merely a treatment with hydrogen, therefore simplifying the activation process.

\subsection{Thioglycolic acid}

Thioglycolic (or mercaptoacetic) acid TGA is water soluble and convenient to use. It is relatively non-toxic and is used as a chemical depilatory and in solutions for hair treatment (creating permanents). This compound is non-expensive as it easily comes from the reactions of basic chemicals [12]'[13]. Chemically TGA is a relatively strong acid: with a pKa of 3.83 it is 100 times stronger than acetic acid, but slightly weaker than citric acid (pKa 3.13).

Being stable in air, however, as most sulfur-containing compounds (thioamides, thiols, etc) thioglycolic acid is prone to be oxidized in aqueous solution forming dithiodiglycolic- acid 
and further, the sequence of sulfur-oxygen exchange compounds, this process being strongly dependent on the solution $\mathrm{pH}[14]$.

It has been reported that thioglycolic acid (on silica gel) is able to extract $\mathrm{Cr}$ (III) and $\mathrm{Fe}(\mathrm{III})$ cations from their ethanolic solutions. It reveals that TGA is a strong chelatant [15]. The potential modes of interaction of TGA with transition metals ions are shown in Figure 2. The exact type of chelation will probably depend on the relative hardness of the corresponding ions (HSAB theory).
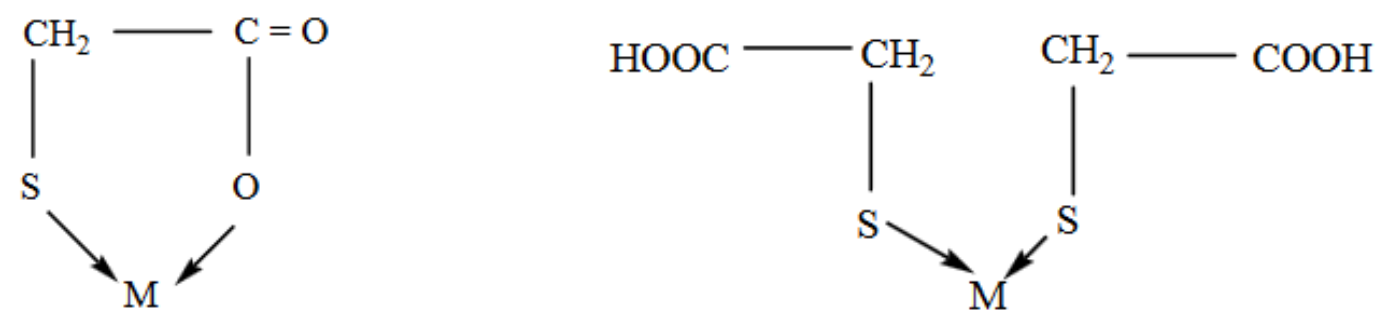

Figure 2. Potential dentation modes of thioglycolic acid

The study of the formation of $\mathrm{Mo}(\mathrm{V})$ complex with thioglycolic acid from $\mathrm{Mo}(\mathrm{VI})$ ion indicates that it acts as a reducing ligand [16]. The interaction between Pt(II) complexes and thioglycolic acid has also been investigated [17].

The chelating properties make it obviously interesting as an agent allowing transport of metal species to a carrier at acidic $\mathrm{pH}$. The first application of such properties was patented in 1974, to disperse the transition metals in the form of TGA complexes [18]. Only in 1992, TGA was applied and patented as a sulfiding agent [19].

Later, Payen et al. applied thioglycolic acid to modify a calcined alumina-supported CoMo catalyst [20]'[21]. The modified oxidic precursors were prepared by incipient wetness impregnation of the CoMo reference catalyst with aqueous solution containing the desired amount of thioglycolic acid to study several TGA/Mo molar ratios. An improvement of the thiophene HDS performances due to TGA addition was observed. It has been assigned to the complexation of the Mo and Co atoms with TGA which induces (i) the increase of the sulfidation degree of the active metals, (ii) the simultaneous sulfidation of the Mo and Co atoms leading to a decrease of the $\mathrm{MoS}_{2}$ slabs length as well as to an increase of the number of Co atoms in decoration position. 
Palcheva et al. studied TGA-modified NiMo sulfide catalysts supported on $\mathrm{Nb}$ modified mesoporous SBA-15 and HMS [22]. Calcined co-impregnated NiMo catalysts were prepared using ammonium heptamolybdate and nickel nitrate. Then NiMo catalysts were treated with TGA at TGA/Mo molar ratio of 4 . For comparison, NiMo catalysts were prepared by a simultaneous impregnation of the supports with $\mathrm{Ni}$, Mo precursors and TGA. Catalyst activity was examined in hydrodesulfurization (HDS) reactions of 1-benzothiophene and thiophene. It was found that simultaneous impregnation by Ni, Mo and TGA led to higher HDS activities than the sequential treatment of the calcined NiMo catalysts by TGA.

Recently, Toledo-Antonio et al. studied the Alumina-supported Mo-based HDS catalysts at $14 \mathrm{wt} \%$ nominal Mo loading [23]. The calcined catalysts were modified by TGA at TGA/Mo = 1 mol ratio. Two series of catalysts were studied, prepared using either ammonium heptamolybdate or phosphomolybdates as a precursor. The corresponding sulfided phases were studied by XPS and HR-TEM-STEM techniques. Formation of ligand-to-metal charge transfer (LMCT) complexes between TGA and Mo atoms, resulted in reduced $\mathrm{Mo}^{5+}$ species, as indicated by XPS and UV-visible spectra obtained on the oxidic precursors. It was concluded that impregnation with TGA redissolves and disperses the $\mathrm{MoO}_{3}$ cystals resulting in sulfide particles with increased stacking of $\mathrm{MoS}_{2}$ slabs, whereas the slabs length remained unaltered. High activity in liquid-phase DBT HDS was attributed to the increase of number of type II sites in sulfided TGA-modified formulations.

These studies carried on versatile systems under different conditions converge in the point of strong chemical impact of TGA: it modifies (redissolves) the ( $\mathrm{Co}, \mathrm{Ni}, \mathrm{Mo})$ oxide phase of the precursor already on the impregnation step and thus species chemically quite different from the initial ones react in subsequent steps of the activation process. However, in the case of optimized CoMo catalyst, as fresh commercial catalyst, impregnation with TGA generally does not lead to beneficial effect. By contrast, it might be very useful to reactivate regenerated catalysts.

\section{Organic additives without $S$}

\subsection{Historical aspect of organic additives and hydrotreating catalysis: from patent start up to academic research}

In the 2000's, a breakthrough in the catalytic activity of industrial hydrotreating catalysts occurred due to the introduction of organic compounds in the preparation procedure. In the 
patent literature, Shell claimed, in 1986, the use of nitrilotriacetic acid (NTA) for the improvement of HDT catalysts [24]. In the 1990's, Sumitomo claimed new types of additive agent with at least one selected from dihydric or trihydric alcohols having $2-10$ carbon atoms per one molecule, ethers of the alcohols, monosaccharides and disaccharides and polysaccharides [25],[26]. At the same period, Cytec proposed various chelating agents [27] and later on, Akzo Nobel patented organic compounds with at least one nitrogen function and one carbonyl function [28],[29]. Since this period many other companies patented their own organic boosters and develop industrial catalysts. These patents are not only limited to the use of specific molecules or functions but also to different preparation methods. A clear distinction can be made between the various additives with those having mainly a solvating effect and those for which complexing/chelating properties have to be considered. In fact, an organic compound can be introduced at various stages of the preparation of the catalyst and can be maintained until the activation stage or intermediately calcined. Thus, an additive can act as a complexing/chelating agent in the impregnation solution or after a treatment (drying, calcination) resulting in the formation of new entities at the surface of the support. This is illustrated by the Figure 3 which schematizes the preparation and regeneration steps of an HDT catalyst and the patents related to the use of organic compounds at each of these stages. According to the stage of the catalyst genesis at which the organic additive is introduced, different properties and different impact can be expected as will be described in details thereafter. 


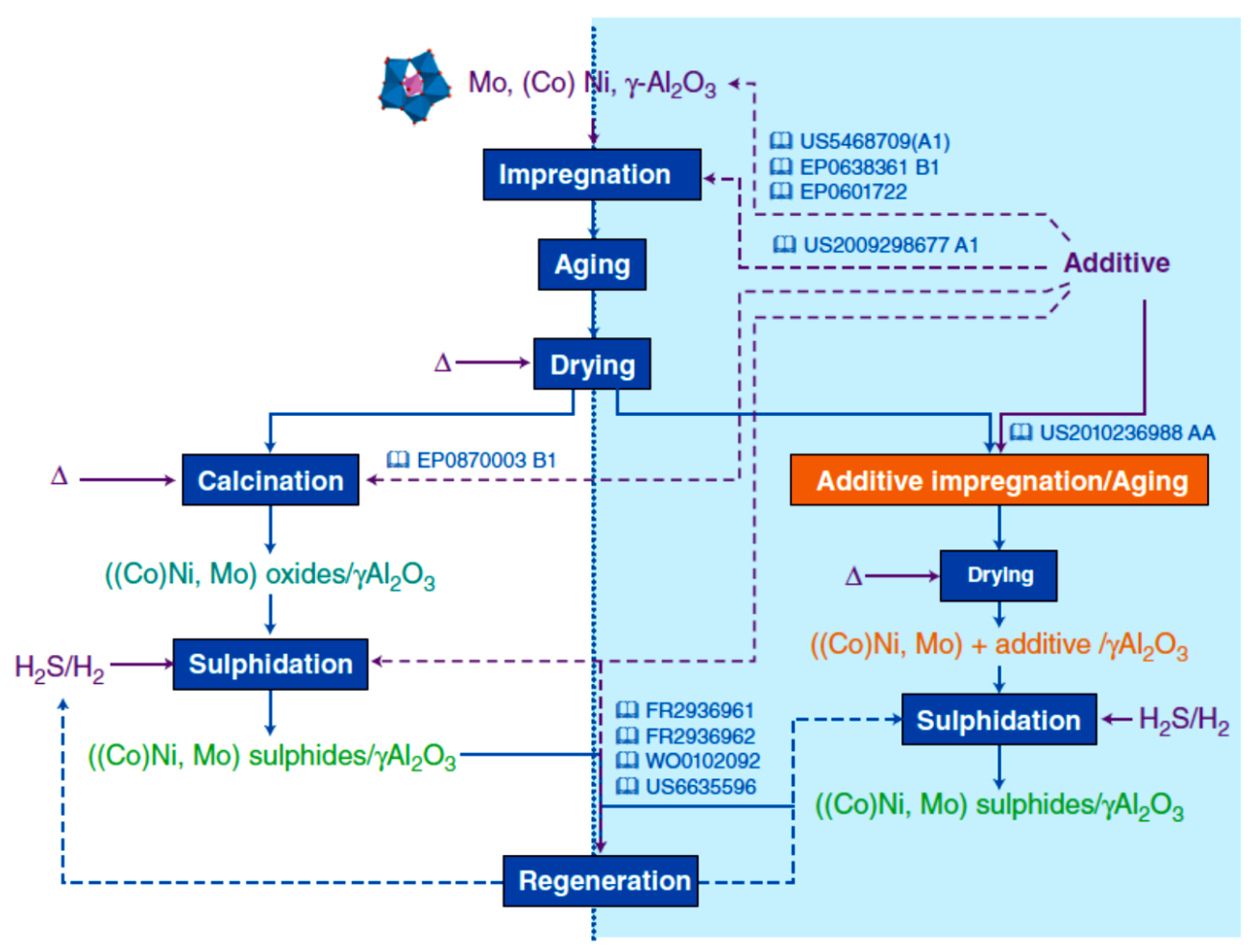

Figure 3. Preparation scheme of a hydrotreating catalyst and patents taken on the different preparation steps [30].

In parallel to the industrial developments, many academic works have been performed in order to clarify the role of these organic compounds and to find new promoters. Thus, in 1987, J.A.R. van Veen et al. proposed the use of nitrilotriacetic acid (NTA) in the one step coimpregnation preparation of a CoMo on alumina catalyst [31]. In 1991, Yoshimura et al. proposed citric acid as a ligand added in precursor solutions which can improve HDT properties for CoMo catalysts as well as ammonia as complexing agent for NiMo catalysts [32]. Academic studies on non-chelating agents attempting to explain the claims from Sumitomo patents were first published in 2003 by Sun et al. who briefly mentioned glycol [33]. Then in 2005 more detailed studies on ethylene glycol (EG) and triethylene glycol (TEG) on CoMoP/Al ${ }_{2} \mathrm{O}_{3}$ catalysts [34] and diethyleneglycolbutylether DEGBE on an industrial CoMoP catalyst [35] were reported. The main studied organic additives are gathered in Figure 4. 

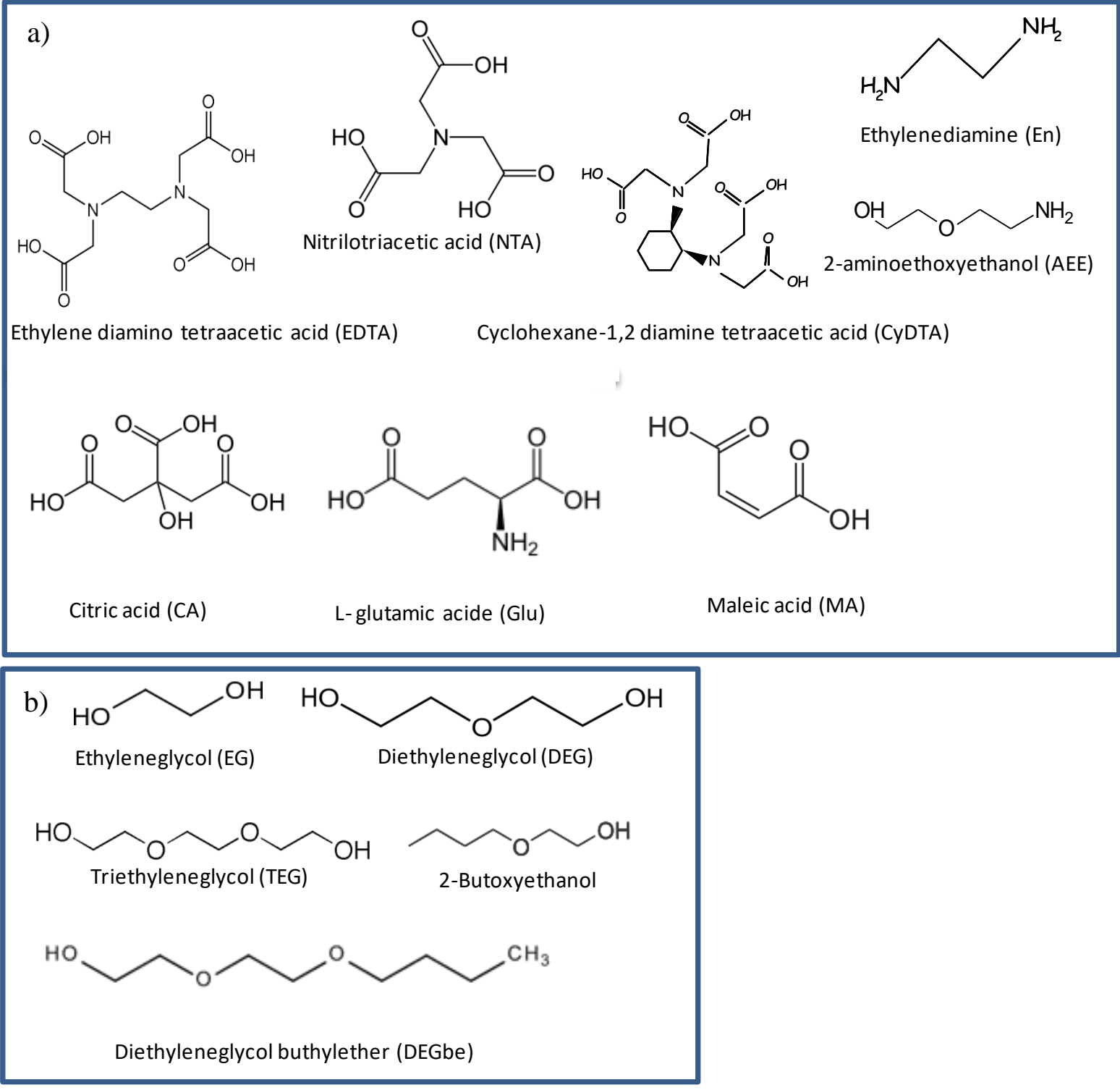

Figure 4. Main organic additives used in HDT catalyst preparation a) complexing agents and b) Non-complexing agents

\subsection{Chelating and complexing additives}

\subsubsection{Characteristics and metal complex formation}

A coordination complex consists of a metallic central atom surrounded by bound molecules known as ligands or complexing agents, thus, giving a metal complex. When a polydentate ligand creates multiple bonds with the metal, the resulting complex is named a metal chelate. The term chelate, derived from the Greek term for claw of the lobster or other crustaceans, is suggested for the caliper like groups, which function as two associating units and fasten to the central atom so as produced heterocyclic rings. In the preparation methods used for HDT 
catalysts, classical (or Werner) complexes are formed via the lone pairs of electrons residing on the main group atoms of the ligand. The affinity of the ligand is described by a stability constant which can vary widely. Coordinating groups include different combinations of one or more of a small number of relatively simple groups $\left(-\mathrm{OH},-\mathrm{COOH},-\mathrm{NH}_{2}\right.$, etc. $)$, each with two or more donor atoms $(\mathrm{O}, \mathrm{N}, \mathrm{S})$ positioned in a way that enables sterically favorable chelates to be readily formed. Of course, this leads to a huge number of complexing/chelating agents, some of the major coordinating sites are illustrated in Figure 5.

Among them, aminopolycarboxylic acids (APCAs) containing several carboxylate groups bound to one or more nitrogen atoms have the ability to form very stable water soluble complexes with many di- or trivalent ions. The $\mathrm{pH}$ value of the aqueous solution is also a parameter of stability of the different complexes and ions.

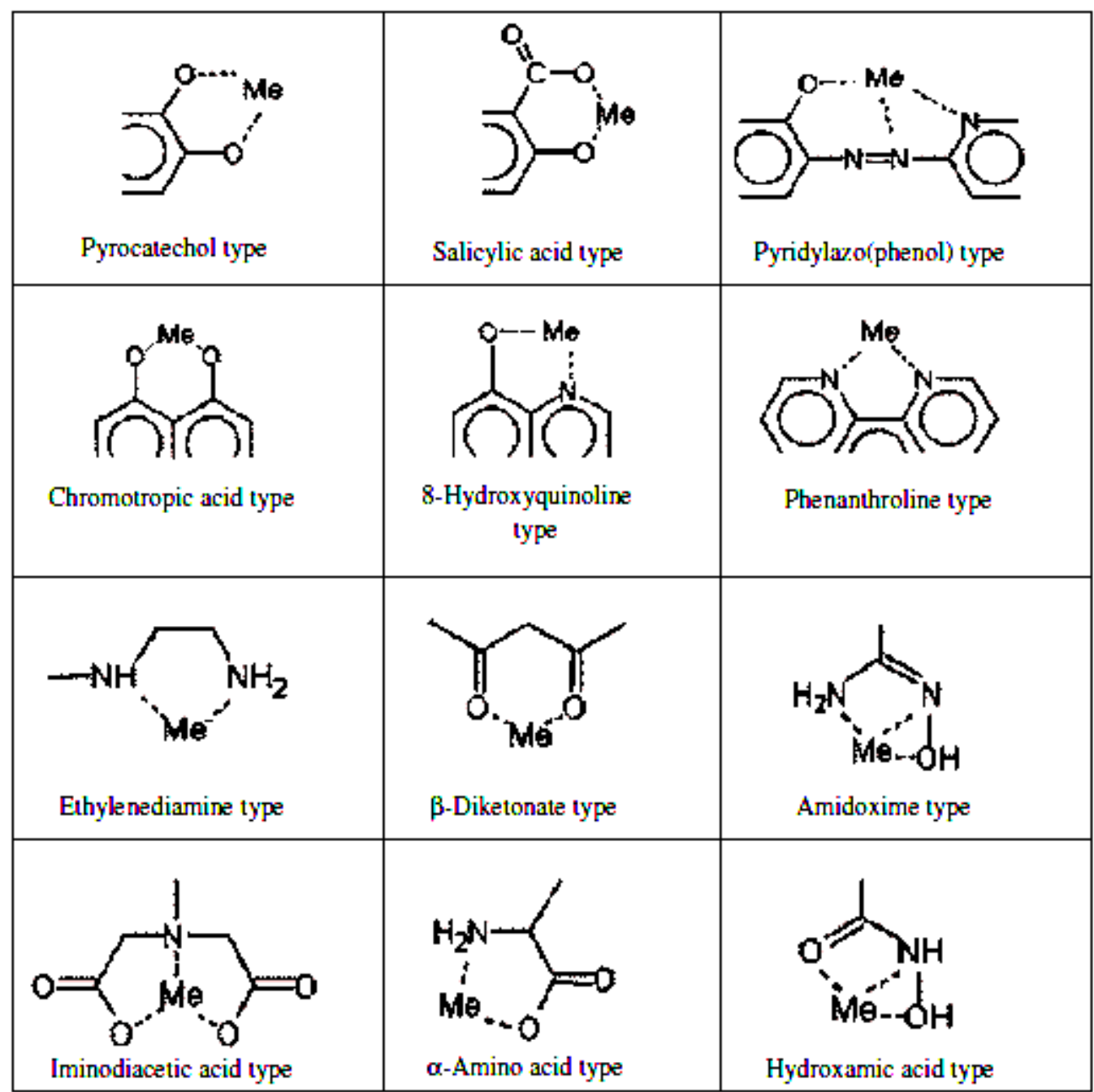

Figure 5. Typical coordinating groups utilized in chelating ion exchangers (from high performance chelation ion chromatography)[36] 
In solution the initial formation of weakly associated ionic pairs with the hydrated metal cation takes place due to electrostatic interactions:

$$
M_{a q}^{y+}+L_{a q}^{-}=\left[M_{a q}^{y+}\right]\left[L_{a q}^{-}\right]
$$

The above associated pair then converts into a stronger formally recognized ion-pair as follows:

$$
\left[M_{a q}^{y+}\right]\left[L_{a q}^{-}\right]=\left[M_{a q}^{y+} L^{-}\right]
$$

Complex formation then follows, with the release of a number of water molecules as the final step:

$$
\left[M_{a q}^{y+} L^{-}\right]=\left[M L^{(y-1)+}\right]+a q u a
$$

The formation of multiple bonds can proceed through a sequence as illustrated by Figure 6 .

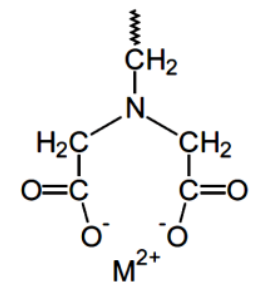

I<smiles>C[C@H]1CC2[Y10](=O)OC(=O)CN2C1</smiles>

॥<smiles>C[C@@H]1CN2CC(=O)O[C@H](C2)O1</smiles>

III

Figure 6. The stepwise interaction of iminodiacetic acid (IDA) functional groups with divalent metal cations

Overall pathways of ligand exchange can lead to complex mechanisms as illustrated by Boland and Stone [37]. Structure III in Figure 6 usually corresponds to the rate-determining process in the formation of the complex. Depending on the metal ion, the rate constant of complexation varies over a wide range (from 10 to $10^{10} \mathrm{~s}^{-1}$ ), the nature of the ligand has also a role on complexation kinetics, anionic forms of ligands being more reactive. The presence of an organic solvent in the aqueous impregnation phase may also affect the kinetic of complexation. 


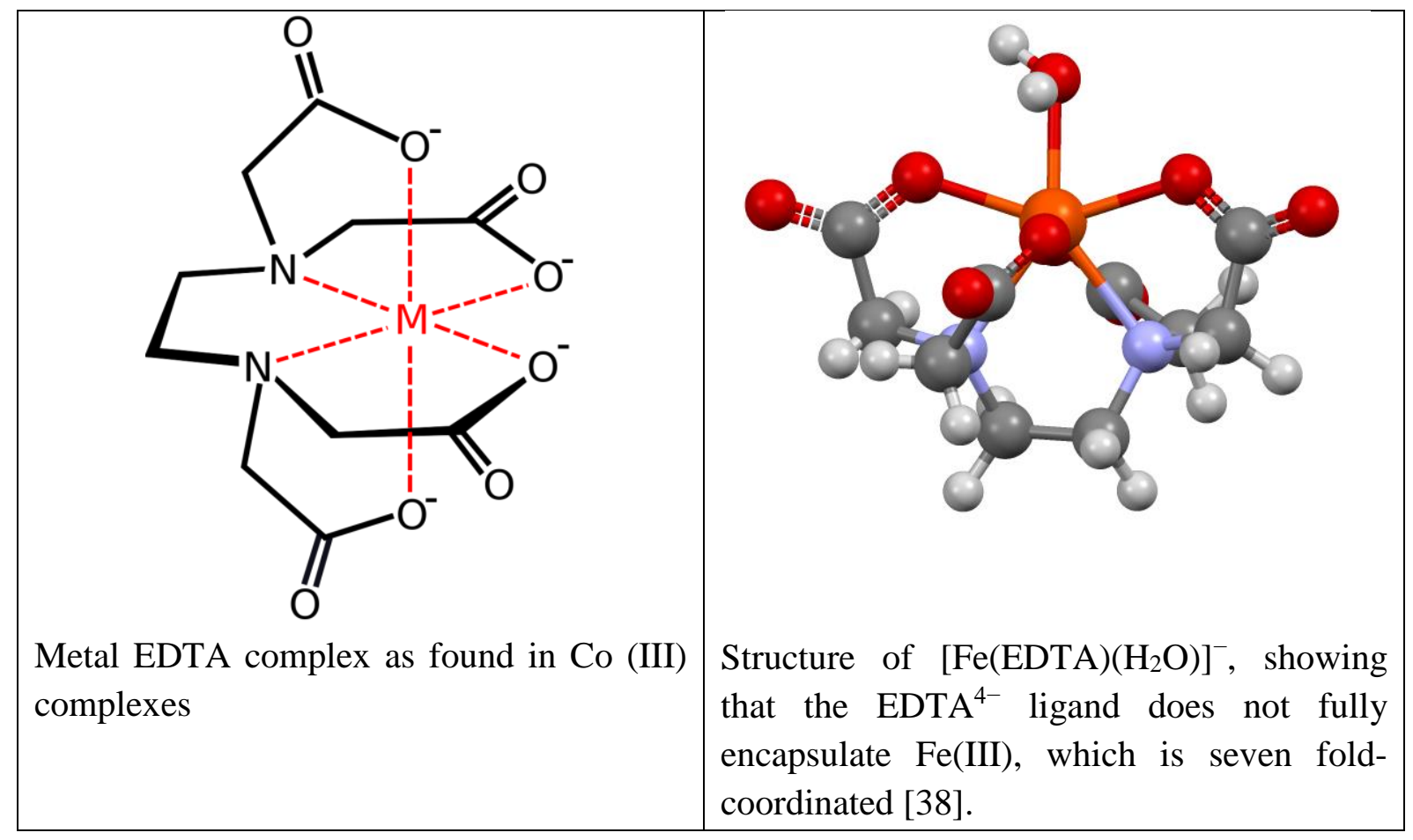

Figure 7. Examples of metal complexes with EDTA

Various complexes can be formed as illustrated by Figure 7 and Figure 8, and the interaction of the surface might modify the predominant conformation due to specific interactions (electrostatic or steric).

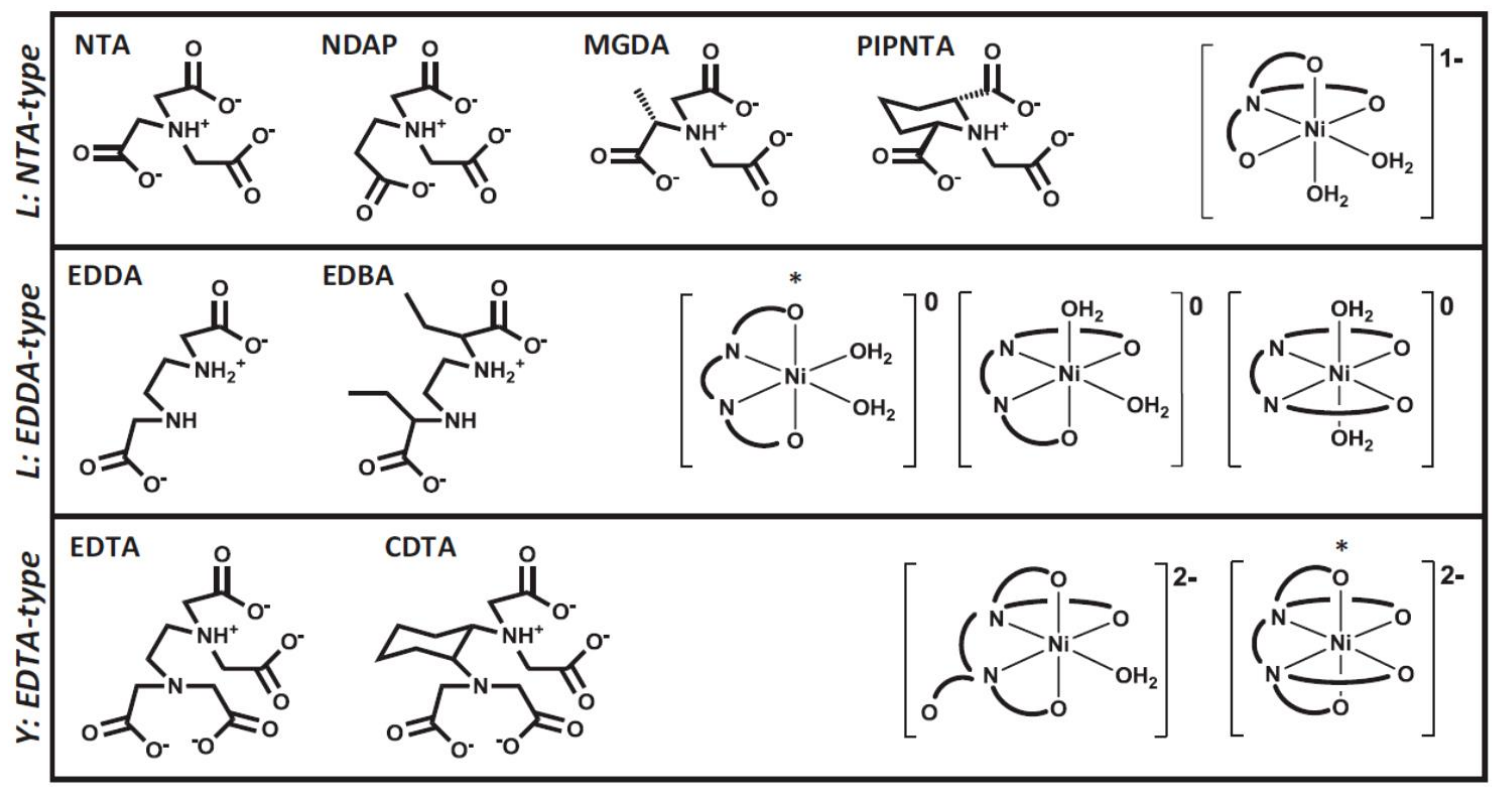

Figure 8. Molecular structures of chelating agents along with conformations of predominant complexes with $\mathrm{Ni}(\mathrm{II})$ at $\mathrm{pH} 7\left(50 \mu \mathrm{M} \mathrm{Ni}_{\text {Total }}\right.$ and $\left.200 \mu \mathrm{lM} \mathrm{L}_{\text {Total }}\right)$. (*denotes the conformation that is calculated to be at the highest concentration at equilibrium)[37] 
Table 1. Some characteristics of chelating agents $[39,40]$

\begin{tabular}{l|c|c|c|c}
\hline Chelating agent & Formula & Boiling point & $\mathrm{pKa}^{\mathrm{a}}$ & $\begin{array}{c}\operatorname{logK1} \\
25^{\circ} \mathrm{C}\end{array}$ \\
\hline $\begin{array}{l}\text { Ethylene } \\
\text { diamine } \\
\text { (En) }\end{array}$ & $\begin{array}{l}\mathrm{C}^{2+}: 5.91 \\
\mathrm{Ni}^{2+}: 7.52\end{array}$ \\
\hline $\begin{array}{l}\text { Diethylene } \\
\text { triamine } \\
\text { (DT) }\end{array}$ & & & & \\
\hline $\begin{array}{l}\text { Nitrilotriacetic } \\
\text { acid } \\
\text { (NTA) }\end{array}$
\end{tabular}

${ }^{a}$ the first constant is indicated, n. d.: not determined 
Considering the various stages of the preparation, differences in the process of metal chelate formation in solution and of an ion grafted on a surface are related to the restricted mobility of the metal ion ligands along that surface. In ionic chromatography, the main difference between complexation in homogeneous and heterogeneous systems is related to the limited conformational mobility of immobilized ligands, in most cases preventing the formation of complexes with stoichiometry other than 1:1. However, when maturation and drying procedure is applied it is possible to observe by XRD the formation of crystalline complexes indicating that upon drying, crystallization of the complexes can easily occur.

This mechanism is also applicable to heterogeneous reaction, the metallic ion being located at the surface of the catalyst either in the inner (IHP) or outer (OHP) Helmholtz plane in the aqueous phase or grafted at the surface after drying (Figure 9).
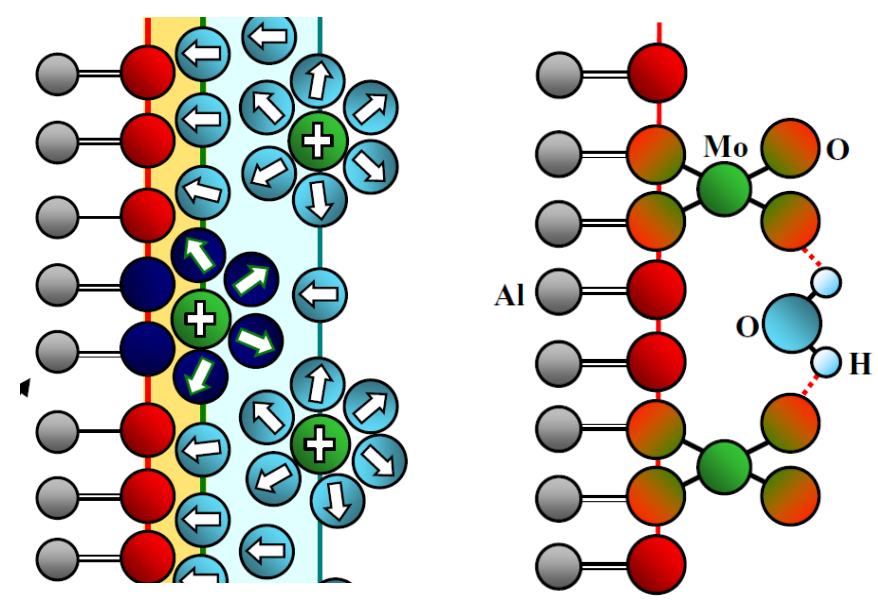

Support IHP OHP

Surface

Figure 9. Schematic view of ion adsorption on a hydrated (left) and dried surface (right) [41]

It has been demonstrated that the support by itself (alumina) can act as a ligand and aluminum can be incorporated in a heteropolyacid (HPA) according to the following reaction:

$$
6 \mathrm{H}^{+}+\mathrm{Al}^{3+}+6 \mathrm{MoO}_{4}^{2-} \leftrightarrows\left[\mathrm{Al}(\mathrm{OH})_{6} \mathrm{Mo}_{6} \mathrm{O}_{18}\right]^{3-}
$$

After drying, these HPA can crystallize and be observed by XRD. The use of complexing/chelating agents (or even non-complexing ones) might compete with this reaction and prevent the formation of aluminum hexamolybdate (Anderson HPA). 
The chelating agents can provide a wide range of properties in solution as summarized in Erreur ! Source du renvoi introuvable.. The $\mathrm{pKa}$ and therefore the $\mathrm{pH}$ of the impregnation solution can be partially controlled by the nature of the additive. Boiling temperature often coincides with a mass loss event in the TGA analysis curves of the impregnated catalysts and the equilibrium constant of the complexes formed in solution might also vary in a wide range. van Haandel et al. [42] by comparing the impact on catalytic performances of weak ( $\alpha$ hydrocarboxylic acids) or strong (aminopolycarboxylic acids) additives, proposed on the basis of the equilibrium constants, that weak complexing agents are more efficient.

\subsubsection{Effects on structure and activity}

In the field of HDT catalysis, the initially used chelating molecules were NTA, EDTA, diAEDTA, 1,2-cyclohexanediamine-N,N,N',N'-tetraacetic (CyDTA) and ethylenediamine (EN). These aminopolycarboxylic acids have been first considered in the literature and extensively studied, but the industrial application faced rapidly the problem of cost. Therefore, alternative compounds were investigated and a focus was made on the specific case of less expensive compounds such as acids and $\alpha$-hydroxycarboxylic acids (AHAs): citric acid (CA), maleic acid (MA), L-glutamic acid (GLU). In an early study, Inamura et al. showed that the addition of Lglutamic acid allows a 60\% increase of catalytic activity in thiophene HDS [43].

Tables 2-5 summarize (i) the catalytic impact of such organic additives (ii) the evidence of additives impact on the physicochemical properties of the catalyst.

It appears that the positive effect of these complexing organic additives on the HDS activity is variable and depends in particular on the stage of introduction, the presence or absence of a calcination step before the sulfidation, the conditions of this sulfidation (gas phase/liquid phase), the composition of the catalyst (in particular presence of phosphorus or not) and the additive/metal ratio. Likewise, when it is observed, the origin of the activity gain is not clearly established. For instance, when addition is performed during the preparation of the support, it might control the growth and morphology and consequently affect the textural properties. For the chelating agents introduced during the impregnation stage, the interactions with metal precursors may affect their reactivity with support surface and thus modify the metal dispersion. These modifications will have an impact on the sulfidation rate and extent of promotion. It is also reported that the chelating agent addition in the impregnation solution modifies the viscosity of the solution upon the drying stage which inhibits the segregation of the metal precursors in the support bodies keeping both the metal and the promoter together 
[43]. Note that organic additives have also a positive effect on non-promoted supported $\mathrm{MoS}_{2}$ activity as in the case for instance of CA [44],[45] and NTA [46]. 
Table 2. Effect of nitrogen containing chelating agent on the activity in HDS and HYD of CoMo(P) NiMo(P) and NiW catalysts

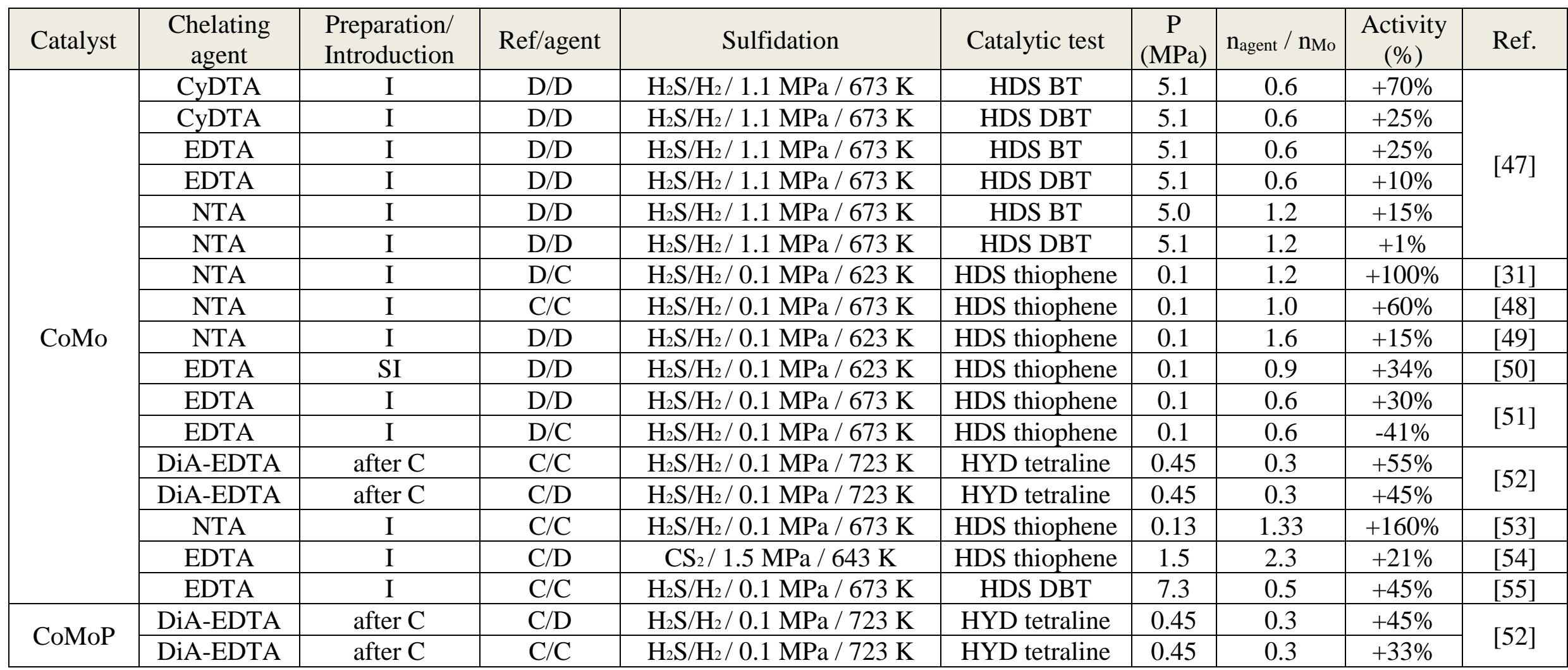

DiA-EDTA: Diammonium ethylenediaminetetraacetate; I: during impregnation; SI: successive impregnation*step before sulfidation of the reference catalyst and of the one prepared with the chelating agent drying (D) / calcination $(\mathrm{C})$ 
Table 3. Effect of carboxylic acids on the activity in HDS of $\mathrm{CoMo}(\mathrm{P}), \mathrm{NiMo}(\mathrm{P})$ and $\mathrm{NiW}$ catalysts

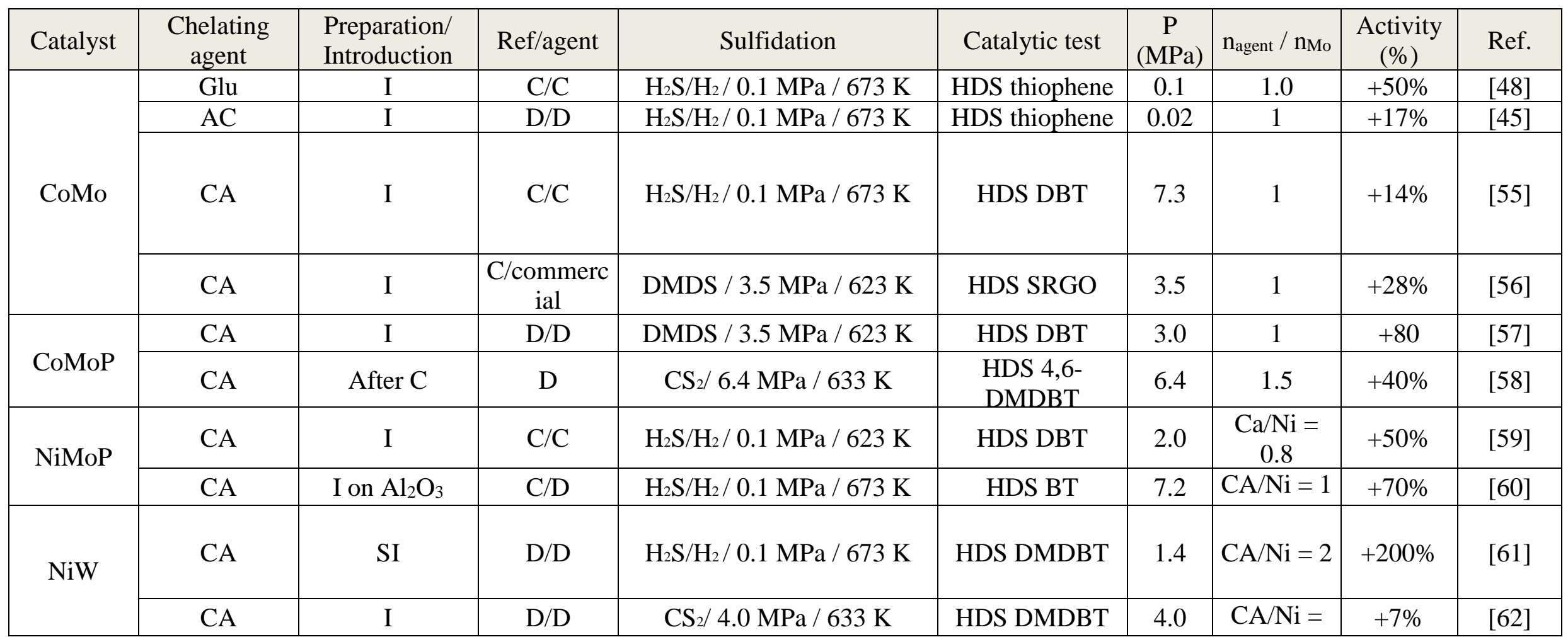


Table 4. Effect of nitrogen containing chelating agent on $\mathrm{CoMo}(\mathbf{P})$ catalysts - Characterization method and conclusion

\begin{tabular}{|c|c|c|c|c|c|c|c|}
\hline Catalyst & $\begin{array}{l}\text { Chelating } \\
\text { agent }\end{array}$ & $\begin{array}{c}\mathrm{n}_{\text {agent }} / \\
\mathrm{n}_{\mathrm{Mo}}\end{array}$ & Introduction & Sulfidation & $\begin{array}{c}\text { Catalyst } \\
\text { characterization }\end{array}$ & Conclusion & Ref. \\
\hline \multirow{14}{*}{ CoMo } & CyDTA & 0.6 & $\mathrm{I}$ & $\mathrm{H}_{2} \mathrm{~S} / \mathrm{H}_{2} / 1.1 \mathrm{MPa} / 673 \mathrm{~K}$ & \multirow{3}{*}{$\begin{array}{c}\text { NO/IR and NO } \\
\text { adsorption }\end{array}$} & \multirow{3}{*}{ Increased dispersion of $\mathrm{Co}$} & \multirow{3}{*}{ [47] } \\
\hline & EDTA & 0.6 & I & $\mathrm{H}_{2} \mathrm{~S} / \mathrm{H}_{2} / 1.1 \mathrm{MPa} / 673 \mathrm{~K}$ & & & \\
\hline & NTA & 1.2 & $\mathrm{I}$ & $\mathrm{H}_{2} \mathrm{~S} / \mathrm{H}_{2} / 1.1 \mathrm{MPa} / 673 \mathrm{~K}$ & & & \\
\hline & NTA & 1.2 & I & $\mathrm{H}_{2} \mathrm{~S} / \mathrm{H}_{2} / 0.1 \mathrm{MPa} / 623 \mathrm{~K}$ & Co Mossbauer & CoMoS type II formation & [31] \\
\hline & NTA & 1.33 & $\mathrm{I}$ & $\mathrm{H}_{2} \mathrm{~S} / \mathrm{H}_{2} / 0.1 \mathrm{MPa} / 673 \mathrm{~K}$ & XPS & Delayed sulfidation of Co & [53] \\
\hline & NTA & 1.6 & I & \multirow{2}{*}{$\mathrm{H}_{2} \mathrm{~S} / \mathrm{H}_{2} / 0.1 \mathrm{MPa} / 623 \mathrm{~K}$} & $\begin{array}{l}\text { CO/IR during } \\
\text { sulfidation }\end{array}$ & $\begin{array}{c}\text { Increased CoMoS sites } \\
\text { concentration }\end{array}$ & [63] \\
\hline & EDTA & 0.9 & $\begin{array}{c}\mathrm{SI} \\
(\mathrm{EDTA}+\mathrm{Co})\end{array}$ & & $\mathrm{CO} / \mathrm{IR}$ & $\begin{array}{c}\text { Increased CoMoS sites } \\
\text { concentration }\end{array}$ & [50] \\
\hline & NTA & 1.0 & r & $\mathrm{H}_{2} \mathrm{~S} / \mathrm{H}_{2} / 0.1 \mathrm{MPa} / 673 \mathrm{~K}$ & $\mathrm{NO} / \mathrm{IR}$ & $\begin{array}{l}\text { Increased dispersion of } \mathrm{Co} \\
\text { Decrease formation of } \mathrm{Co}^{-}, \mathrm{Al}_{2} \mathrm{O}_{3} \\
\text { and } \mathrm{CoMoO}_{4}\end{array}$ & [48] \\
\hline & EDTA & 0.6 & $\mathrm{I}$ & $\mathrm{H}_{2} \mathrm{~S} / \mathrm{H}_{2} / 0.1 \mathrm{MPa} / 673 \mathrm{~K}$ & \multirow{2}{*}{$\begin{array}{l}\text { NO/IR and CO, } \\
\text { TPS }\end{array}$} & \multirow{2}{*}{$\begin{array}{c}\text { Delayed sulfidation of Co } \\
\text { Promotion degree enhancement }\end{array}$} & \multirow{2}{*}{ [51] } \\
\hline & EDTA & 0.6 & $\mathrm{I}$ & $\mathrm{H}_{2} \mathrm{~S} / \mathrm{H}_{2} / 0.1 \mathrm{MPa} / 673 \mathrm{~K}$ & & & \\
\hline & EDTA & $2.3-3.6$ & $\mathrm{I}$ & $\mathrm{CS}_{2} / 1.5 \mathrm{MPa} / 643 \mathrm{~K}$ & $\mathrm{CO} / \mathrm{IR}$ & Increased CoMoS site concentration & [54] \\
\hline & DiA-EDTA & 0.3 & after $\mathrm{C}$ & $\mathrm{H}_{2} \mathrm{~S} / \mathrm{H}_{2} / 0.1 \mathrm{MPa} / 723 \mathrm{~K}$ & \multirow{2}{*}{ TPS, Raman } & \multirow{2}{*}{$\begin{array}{c}\text { Delayed sulfidation of } \mathrm{Co} \\
\text { Extraction of Co from } \mathrm{CoMoO}_{4}\end{array}$} & \multirow{2}{*}{ [52] } \\
\hline & DiA-EDTA & 0.3 & after $\mathrm{C}$ & $\mathrm{H}_{2} \mathrm{~S} / \mathrm{H}_{2} / 0.1 \mathrm{MPa} / 723 \mathrm{~K}$ & & & \\
\hline & EDTA & 0.5 & I & $\mathrm{H}_{2} \mathrm{~S} / \mathrm{H}_{2} / 0.1 \mathrm{MPa} / 673 \mathrm{~K}$ & $\begin{array}{l}\text { XRD, UV-vis, } \\
\text { TPR, HRTEM }\end{array}$ & $\begin{array}{l}\text { No formation of } \mathrm{CoMoO}_{4} \\
\text { Better dispersion of metal }\end{array}$ & [55] \\
\hline \multirow{2}{*}{$\mathrm{CoMoP}$} & DiA-EDTA & 0.3 & after $\mathrm{C}$ & $\mathrm{H}_{2} \mathrm{~S} / \mathrm{H}_{2} / 0.1 \mathrm{MPa} / 723 \mathrm{~K}$ & \multirow{2}{*}{ TPS, Raman } & \multirow{2}{*}{$\begin{array}{c}\text { Delayed sulfidation of } \mathrm{Co} \\
\text { Extraction of Co from } \mathrm{CoMoO}_{4}\end{array}$} & \multirow{2}{*}{ [52] } \\
\hline & DiA-EDTA & 0.3 & after $\mathrm{C}$ & $\mathrm{H}_{2} \mathrm{~S} / \mathrm{H}_{2} / 0.1 \mathrm{MPa} / 723 \mathrm{~K}$ & & & \\
\hline
\end{tabular}

DiA-EDTA: Diammonium ethylenediaminetetraacetate; I: during impregnation; SI: successive impregnation 
Table 5. Effect of carboxylic acid on $\mathrm{CoMo}(\mathrm{P}), \mathrm{NiMo}(\mathrm{P})$ and NiW catalysts - Characterization method and conclusion

\begin{tabular}{|c|c|c|c|c|c|c|c|}
\hline Catalyst & $\begin{array}{c}\text { Chelating } \\
\text { agent }\end{array}$ & $\mathrm{n}_{\mathrm{agent}} / \mathrm{n}_{\mathrm{Mo}}$ & Introduction & Sulfidation & Catalyst characterization & Conclusion & Ref. \\
\hline \multirow{5}{*}{ CoMo } & Glu & 1 & I & $\begin{array}{l}\mathrm{H} 2 \mathrm{~S} / \mathrm{H} 2 / 0.1 \\
\mathrm{MPa} / 673 \mathrm{~K}\end{array}$ & NO/IR & $\begin{array}{c}\text { Increased dispersion of Co } \\
\text { Decrease formation of } \mathrm{Co}^{-} \mathrm{Al}_{2} \mathrm{O}_{3} \text { and } \mathrm{CoMoO}_{4}\end{array}$ & [48] \\
\hline & $\mathrm{CA}$ & 1 & I & $\begin{array}{l}\mathrm{H} 2 \mathrm{~S} / \mathrm{H} 2 / 0.1 \\
\mathrm{MPa} / 673 \mathrm{~K}\end{array}$ & $\begin{array}{l}\text { XRD, UV-vis, TPR, } \\
\text { HRTEM }\end{array}$ & $\begin{array}{l}\text { No formation of } \mathrm{CoMoO}_{4} \\
\text { Better dispersion of metal } \\
\end{array}$ & [55] \\
\hline & $\mathrm{CA}$ & & I & $\begin{array}{l}\mathrm{H} 2 \mathrm{~S} / \mathrm{H} 2 / 0.1 \\
\mathrm{MPa} / 673 \mathrm{~K}\end{array}$ & XPS, TPO, EXAFS & Increase number of CoMoS & {$[32]$} \\
\hline & $\mathrm{CA}$ & 1 & I & $\begin{array}{l}\mathrm{H} 2 \mathrm{~S} / \mathrm{H} 2 / 0.1 \\
\mathrm{MPa} / 673 \mathrm{~K}\end{array}$ & Raman, EXAFS & Increased dispersion of Mo & [45] \\
\hline & $\mathrm{CA}$ & 1 & I & $\begin{array}{l}\mathrm{DMDS} / 3.5 \\
\mathrm{MPa} / 623 \mathrm{~K}\end{array}$ & $\begin{array}{l}\text { TGA, DSC, TPO, Raman, } \\
\text { TPR-MS, HRTEM, XRD, }\end{array}$ & Uniform deposition of Co and Mo complexes & {$[56]$} \\
\hline \multirow[b]{2}{*}{$\operatorname{CoMo}(\mathrm{P})$} & $\mathrm{CA}$ & 1 & I & $\begin{array}{l}\mathrm{DMDS} / 3.5 \\
\mathrm{MPa} / 623 \mathrm{~K}\end{array}$ & Raman, TPR, XPS, HRTEM & $\begin{array}{c}\text { Promotion degree enhancement Increased Mo } \\
\text { dispersion and } \\
\text { stacking number }\end{array}$ & {$[57]$} \\
\hline & $\mathrm{CA}$ & $\begin{array}{l}\mathrm{CA} / \mathrm{Co} \\
=0-1.5\end{array}$ & After C & $\begin{array}{c}\mathrm{CS} 2 / 6.4 \mathrm{MPa} / \\
633 \mathrm{~K}\end{array}$ & $\begin{array}{c}\text { TPR, FTIR, TG-MS, Raman, } \\
\text { XRD, DRS UV-vis, XPS, } \\
\text { HRTEM }\end{array}$ & $\begin{array}{c}\text { Redispersion of Co, Mo by } \\
\text { (i) decrease of } \mathrm{MoO}_{3} \text {-support interaction (ii) } \\
\text { formation of polymolybdate and well dispersed } \\
\mathrm{MoO}_{3} \text { (iii) removal of } \mathrm{CoAl}_{2} \mathrm{O} 3 \text { Enhanced } \\
\text { sulfidation degree }\end{array}$ & {$[58]$} \\
\hline \multirow{2}{*}{ NiMoP } & $\mathrm{CA}$ & $\begin{array}{c}\mathrm{CA} / \mathrm{Ni}= \\
0.8\end{array}$ & I & $\begin{array}{l}\mathrm{H} 2 \mathrm{~S} / \mathrm{H} 2 / 0.1 \\
\mathrm{MPa} / 623 \mathrm{~K}\end{array}$ & NO adsorption, XPS, TPR & Increase Ni-Mo-S active phase formation & [59] \\
\hline & $\mathrm{CA}$ & $\mathrm{CA} / \mathrm{Ni}=1$ & On $\mathrm{Al}_{2} \mathrm{O}_{3}$ & $\begin{array}{l}\mathrm{H} 2 \mathrm{~S} / \mathrm{H} 2 / 0.1 \\
\mathrm{MPa} / 673 \mathrm{~K} \\
\end{array}$ & UV-visible, IR, TPR, TGA & $\begin{array}{l}\text { Decrease of support active phase interaction by } \\
\text { passivation of } \mathrm{OH} \text { groups by } \mathrm{CA}\end{array}$ & {$[60]$} \\
\hline \multirow{2}{*}{$\mathrm{NiW}$} & $\mathrm{CA}$ & $\mathrm{CA} / \mathrm{Ni}=2$ & $\begin{array}{c}\mathrm{SI} \\
(\mathrm{CA}+\mathrm{Ni})\end{array}$ & $\begin{array}{l}\mathrm{H} 2 \mathrm{~S} / \mathrm{H} 2 / 0.1 \\
\mathrm{MPa} / 673 \mathrm{~K}\end{array}$ & $\begin{array}{c}\text { Uv-Vis, IR, TPR, HRTEM, } \\
\text { XPS }\end{array}$ & $\begin{array}{c}\text { Decrease of support active phase interaction } \\
\text { Delayed reduction of Ni } \\
\text { Decrease of } \mathrm{WS}_{2} \text { sintering }\end{array}$ & {$[61]$} \\
\hline & CA & $\begin{array}{c}\mathrm{CA} / \mathrm{Ni}= \\
1.2\end{array}$ & I & $\begin{array}{c}\mathrm{CS} 2 / 4.0 \mathrm{MPa} / \\
633 \mathrm{~K}\end{array}$ & Uv-Vis, TPO, HRTEM, XPS & $\begin{array}{c}\text { Decrease of } \mathrm{WS}_{2} \text { slab length } \\
\text { Increase Ni-W-S active phase formation } \\
\text { Decrease of support active phase interaction }\end{array}$ & {$[62]$} \\
\hline
\end{tabular}


For the Co promoted Mo catalysts, it is proposed that the complexation of cobalt causes (i) a delay in the sulfidation of Co which would then take place at the same time as or after that of molybdenum and then increase the quantity of promoted sites[64],[65]; (ii) an increase in the amount of cobalt used for decoration (reduction of the Co insertion in alumina, dissolution of $\mathrm{CoMoO}_{4}$ oxide); (iii) a modification of the nature of the formed sites (CoMoS type II instead of CoMoS type I)[31],[66]. However, the complex formed does not always imply the promoter but can also be formed with Mo. This is the case when CA is used. It has been reported by Bergweff et al. that at the pH classically used for the preparation (less than 2), the more stable complex is $\mathrm{Mo}_{4}(\text { Hcitrate })_{2} \mathrm{O}_{11}{ }^{4-}$ [67]. Formation of this complex is beneficial to limit the interaction between the Mo precursor and the alumina support favoring the simultaneous migration of the Co and Mo complexes inside the alumina pellet during the impregnation step.

For Ni-Mo catalysts, the formation of NiMoS type II upon addition of NTA was also claimed by van Veen et al. to explain the activity gain (+17\%) in HDN of quinoline[68]. Prins et al. studied the influence of several additives (EDTA, NTA, ethylenediamine (EN)) on $\mathrm{NiMo} / \mathrm{SiO}_{2}[69-72]$ and $\mathrm{NiMo} / \mathrm{Al}_{2} \mathrm{O}_{3}$ catalysts [73]. In the case of silica support for which weaker interactions occur than on alumina, the formation of complexes leads to delayed sulfidation and better dispersion of $\mathrm{Ni}$. In the case of $\mathrm{Ni}(\mathrm{W})$ catalysts, improved activity in thiophene HDS is also attributed to the formation of a Ni complex which delayed the sulfidation of $\mathrm{Ni}$ (i) to temperature where $\mathrm{W}$ is getting sulfided in the case of NTA and EDTA (ii) to temperature where $\mathrm{W}$ is already sulfided in the case of CyDTA [74],[75]. Thus, the promoter will interact only with sulfided $\mathrm{WS}_{2}$ slabs providing more decorated NiWS sites. Similar results were obtained on CoW system with CyDTA and triethylenetetraamine hexa acetic acid (TTHA)[76].

It was also demonstrated by Blanchard et al.[77] that the formation of $\mathrm{CoMoO}_{4}$ or $\mathrm{Co}_{3} \mathrm{O}_{4}$ (poor precursors for CoMoS) are prevented with EDTA addition. Mazoyer et al. have shown that these phases are consumed by DiA-EDTA, leading to the redispersion of Co atoms at the surface of the catalyst [52]. Likewise, redispersion effect and activity promotion of CA on $\mathrm{CoMo} / \mathrm{Al}_{2} \mathrm{O}_{3}$ catalysts were shown to: (i) weaken $\mathrm{MoO}_{3}-\mathrm{Al}_{2} \mathrm{O}_{3}$ interaction through competitive reaction with hydroxyl groups of $\mathrm{Al}_{2} \mathrm{O}_{3}$; (ii) transform $\mathrm{MoO}_{4}{ }^{2-}$ and $\beta-\mathrm{CoMoO}_{4}$ into polymolybdate and promote bulk $\mathrm{MoO}_{3}$ into well-dispersed $\mathrm{MoO}_{3}$, (iii) remove the $\mathrm{CoAl}_{2} \mathrm{O}_{4}$ like species [58]. 
Few academic works have addressed the issue of complexing agent selectivity toward $\mathrm{Co}(\mathrm{Ni})$ vs. $\mathrm{Mo}(\mathrm{W})$ in the case of HDT catalysts. However, in the $\mathrm{PhD}$ work of Mazoyer, the use of 2-aminoethoxyethanol (AEE), was found to be selective to Mo complexation [78]. Klimov et coll.[79] studied the activation of a $\mathrm{CoMo} / \mathrm{Al}_{2} \mathrm{O}_{3}$ catalyst prepared with citric acid and evidenced the formation of a mixed $\mathrm{Co}$ and Mo complex: $\mathrm{Co}_{2}\left[\mathrm{Mo}_{4}\left(\mathrm{C}_{6} \mathrm{H}_{5} \mathrm{O}_{7}\right)_{2} \mathrm{O}_{11}\right]$ (Figure 10). In the opposite, Escobar et al. reported that simultaneous Ni-Mo-P-CA deposition leads to a low $\mathrm{pH}$ of impregnating solution $(\mathrm{pH} \sim 1.4)$ devoid of citric acid anions (then, no citrate complex formation). In such a low-pH solution CA was ineffective in improving HDS activity [60].

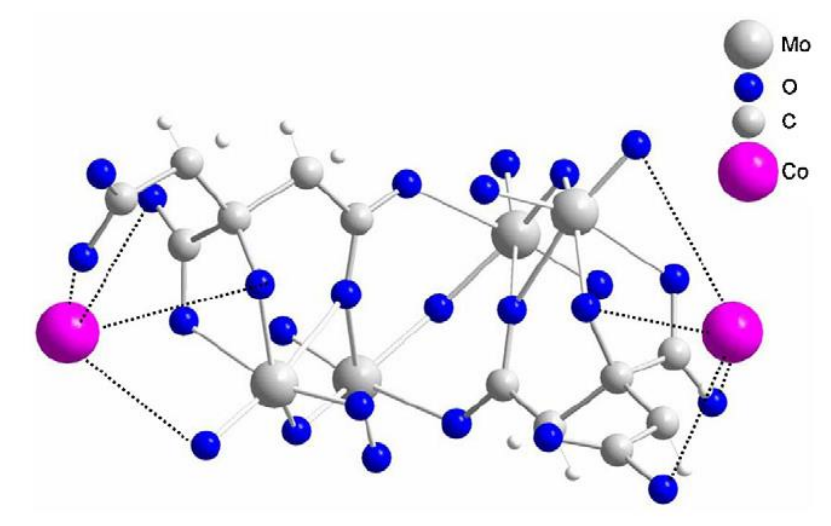

Figure 10. Proposed structure for $\mathrm{Co}_{2}\left[\mathrm{Mo}_{4}\left(\mathrm{C}_{6} \mathrm{H}_{5} \mathrm{O}_{7}\right)_{2} \mathrm{O}_{11}\right]$ complex [79]

The $\alpha$-hydroxycarboxylic acids (CA, Tartaric acid (TA) and Gluconic acid (GA)) form weak complexes with cobalt that readily decompose at 20 bar in $\mathrm{H}_{2} \mathrm{~S}_{2} \mathrm{H}_{2}$, resulting in sulfidation at earlier stage of the activation process. Aminopolycarboxylic acids (NTA, EDTA) form cobalt chelates of higher stability, of which the cobalt-EDTA complex is least affected by $\mathrm{H}_{2} / \mathrm{H}_{2} \mathrm{~S}$ pressure [42]. However, catalyst samples prepared with weak chelating agents (CA, TA, GA) are the most active and have the highest degree of promotion. This is attributed to enhanced reducibility of molybdenum as well as to lowered metal-support interactions [42]. Identification of the Co complex formed upon maleic acid addition on regenerated samples was performed by Bui et al. [80] (Figure 11). Similarly, as for as prepared catalyst, the maleic acid allows the extraction of $\mathrm{Co}$ from $\mathrm{CoMoO}_{4}$ phase in regenerated samples. 


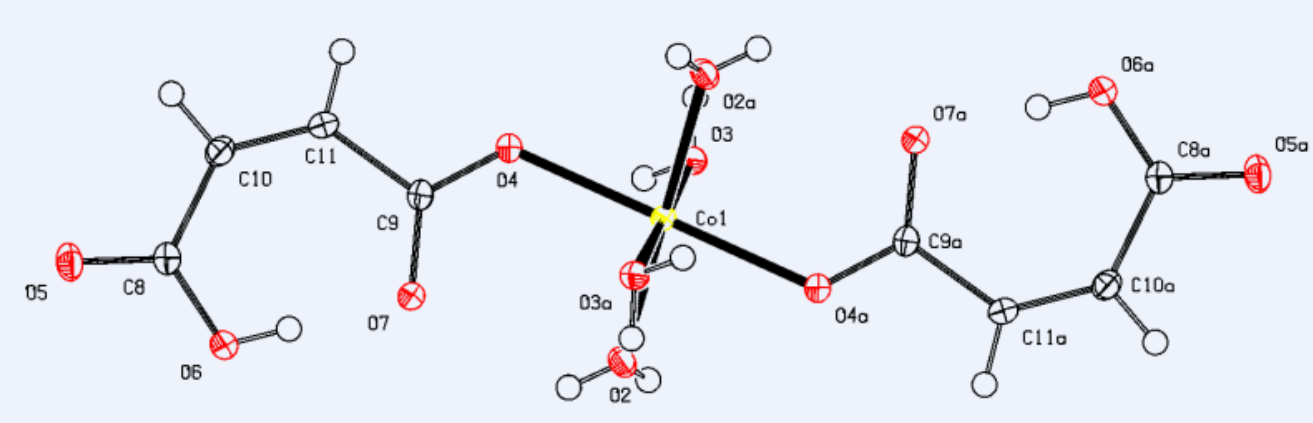

Figure 11. Crystal structure of monodentate cobalt maleate $\mathrm{Co}\left(\mathrm{C}_{4} \mathrm{H}_{3} \mathrm{O}_{4}\right)_{2.4} \mathrm{H}_{2}[80]$

IR spectroscopy characterization has been used to identify the role of chelating agent addition in the formation of the active sites. Lelias et al. have shown, following the sulfidation process with and without NTA by IR, that the additive interacts with the alumina support limiting the loss of Co in spinel and thus favoring formation of the promoted sites [63]. They have also shown, in a subsequent study, that no modification of the slab length and stacking occurs with addition of NTA while the concentration of edge sites increases [49]. Meanwhile, the modification of the active site properties suggested a modification of the nature of the sites. Several hypotheses were proposed such as the formation of CoMoS type II, the formation of $\operatorname{CoS}_{\mathrm{x}}$ clusters in the neighborhood of the slab and the formation of mixed CoMoSN sites. Similar conclusions were obtained on the EDTA effect [50]. In the case of CA, the same group has shown the modification of the slab morphology through the distinction of the S-edge and M-edge exposed by the slab with CO adsorption followed by IR spectroscopy [44]. Addition of CA, thus, leads to the formation of more hexagonal shaped Mo slab exposing more S-edge sites and leading to the formation of higher concentration of CoMoS sites [81].

A mixture of organic chelating additives such as ethylenediamine and a carboxylic acid was also investigated [82]. The assumption for using such a mixture was the specific complexation of Co with EDA and of Mo with a carboxylic acid. This combination can lead in solution to $\mathrm{NH}_{4}\left(\mathrm{enH}_{2}\right)_{\mathrm{x}}\left[\mathrm{Co}(\mathrm{en})_{3}\right]\left[\mathrm{Mo}_{2} \mathrm{O}_{7} \mathrm{~L}\right] \cdot \mathrm{H}_{2} \mathrm{O}$ complexes with $\mathrm{L}$ corresponding to the carboxylic acid. This complex was impregnated on a $\gamma$ alumina. Upon calcination, the complex is decomposed between $200-300{ }^{\circ} \mathrm{C}$ and the optimum calcination temperature with respect to HDS activity was found to be $400{ }^{\circ} \mathrm{C}$.

\subsection{Non-chelating additives}


As compared to chelating agents, it is considered that no (or weak) complexes are formed with non-chelating agents, and therefore since only weak interactions exist, calcination must be avoided in order to keep the benefit of the interaction of the additive with the support or with the precursor phase. A short list of this type of additives is given in Table 6. Several assumptions have been made in order to explain the beneficial effect observed.

J. A. van Dillen et al. proposed that the viscosity increase may have a beneficial effect on the active phase dispersion and consequently on the catalytic activity [43]. According to the author, since the solvent evaporation takes place at the exterior of the support particles, the capillary flow of the solution to its exterior surface may take place, thereby causing the production of egg-shell catalysts, often with poor dispersion of the active phase. An increase in the impregnation solution viscosity suppresses the solution outward flow and leads to more uniform profiles over the support bodies. Indeed, increase in the viscosity of the solution during drying is reported and would explain a homogeneous dispersion of the active components as well as their weak interaction with the support [43]. The presence of the additive, by reacting with basic $\mathrm{Al}-\mathrm{OH}$ and $\mathrm{Al}^{3+}$ alumina sites may hinder the interaction of the precursors with the support surface[83]. Costa et al.[84] by studying different ways of impregnation for various $\mathrm{CoMoP} / \mathrm{Al}_{2} \mathrm{O}_{3}$ catalysts demonstrate that the presence of the TEG modifies the distribution of HPA at the surface of the alumina and induces redispersion of the oxidic compounds. UV and Raman analysis demonstrated that Co is mostly impacted and proportion between $\mathrm{Co}$ (II) and Co(III) is impacted by the presence of the additive [84]. Such an effect has an impact of the sulfidation rates of the Mo and Co and like chelating agents leads to a delay in the sulfidation rates of either Mo or Co with TEG, DEGBE [35],[52],[85]. 
Table 6. Boiling point or melting point or decomposition temperature and viscosity at $20^{\circ} \mathrm{C}$ of the alcohols and ethers use as additives

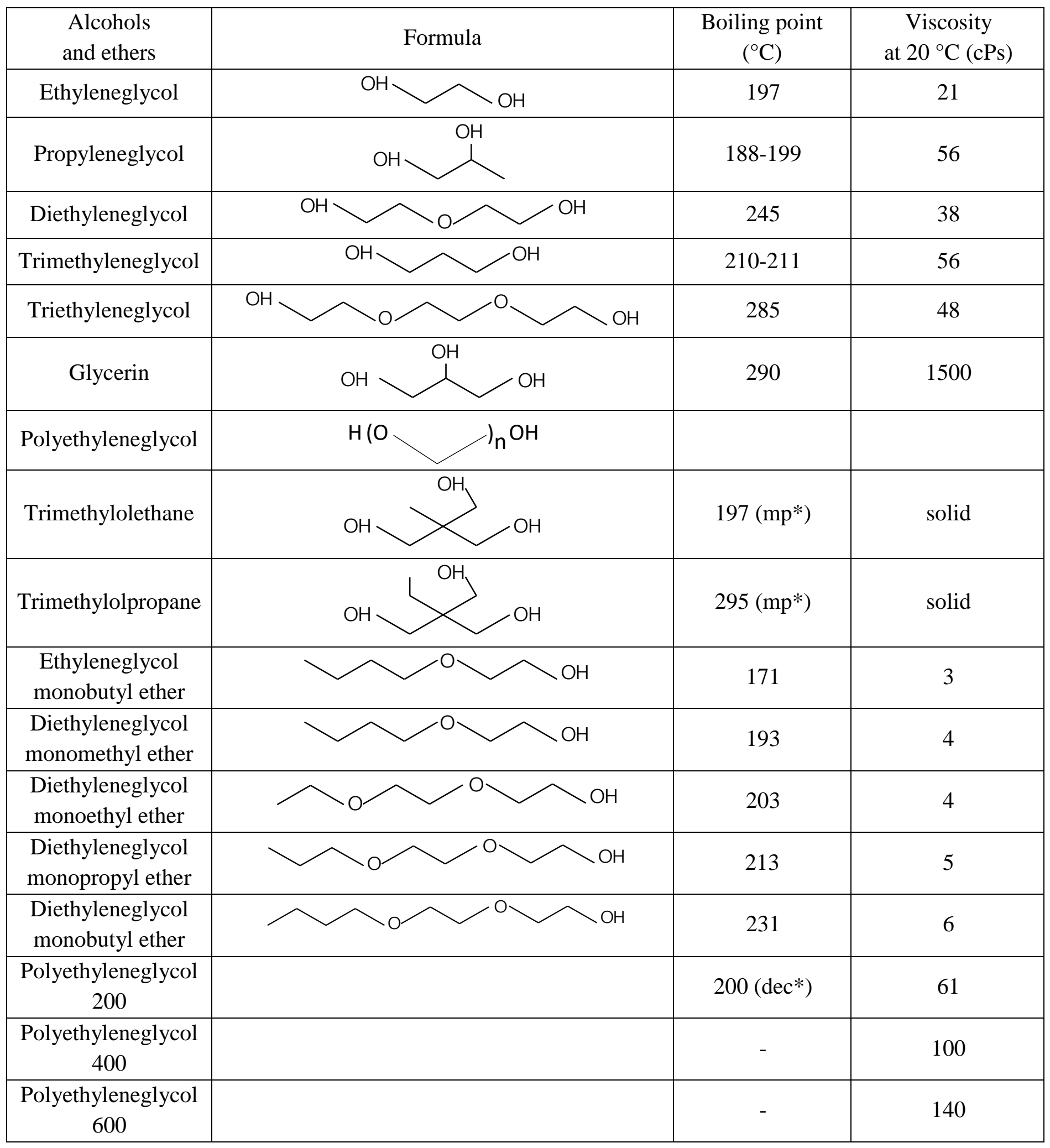

*mp = melting point; $\mathrm{dc}=$ decomposition 


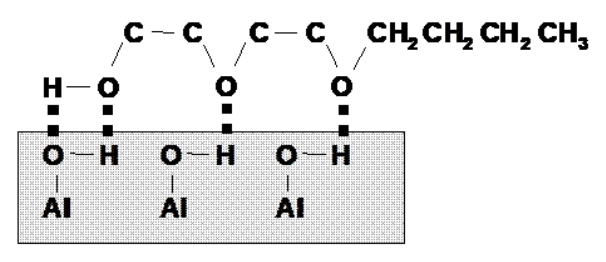

Figure 12. Schematic representation of hydrogen bonding possibilities for DEGbe adsorption over alumina

Interaction of non chelating agent with the alumina support can be described by hydrogen bonding (Figure 12). To this weak hydrogen interaction, we should add the possibility of coordination between $\mathrm{Al}^{3+}$ Lewis acidic sites and the basic ether oxygen of PEG (Lewis acid-base interaction), as well as electrostatic interaction between positively charged alumina surface and feebly negatively charged ethoxy oxygen of PEG, bellow $\mathrm{pH} 9$ (isoelectrical point of alumina, IEP). All these interactions depend on $\mathrm{pH}$.

As a consequence, alumina becomes less reactive to water and using these organic compounds, it is possible to prevent reaction with water and creation of boehmite. Even if the interaction with the Mo or Co oxides are weak, the high boiling point of these organic compounds delayed the sulfidation as observed for TEG by Nicosia et al. [34], and for DEGBE by Mazoyer et al.[35]. Costa concluded in his $\mathrm{PhD}$, related to the use of organic promoters in combination with HPA, that glycol type additives improve the dispersion of the oxidic precursors leading to a higher number of well promoted CoMoS sites [86]. T. S. Nguyen et al. evidenced that triethylene glycol (TEG) modifies the nature of molybdenic species by reducing the polymerization state of molybdates [85]. The Table 7 and Table 8 summarize the impact of non-chelating agents on the physicochemical properties and catalytic activity of the catalysts. 
Table 7. Effect of non-chelating agent on sulfide catalysts - Characterization method and conclusion

\begin{tabular}{|c|c|c|c|c|c|c|c|c|}
\hline Catalyst & $\begin{array}{l}\text { Non- } \\
\text { chelating } \\
\text { agent }\end{array}$ & $\begin{array}{l}\mathrm{n}_{\text {agent }} \\
/ \mathrm{n}_{\mathrm{Mo}}\end{array}$ & Introduction & $\begin{array}{l}\text { Ref / } \\
\text { agent* }\end{array}$ & Sulfidation & $\begin{array}{l}\text { Catalyst } \\
\text { characterization }\end{array}$ & Conclusion & Ref. \\
\hline Mo and CoMoP & PEG & 1.0 & $\mathrm{I}$ & $\mathrm{D} / \mathrm{D}$ & $\mathrm{H}_{2} \mathrm{~S} / \mathrm{H}_{2} / 0.1$ or $2 \mathrm{MPa} / 623 \mathrm{~K}$ & XAS, TEM, XPS & Favors formation of polymolybdates & [42] \\
\hline \multirow{6}{*}{ CoMoP } & TEG & 0.83 & I & $\mathrm{D} / \mathrm{D}$ & $\mathrm{H}_{2} \mathrm{~S} / \mathrm{H}_{2} / 0.1 \mathrm{MPa} / 673 \mathrm{~K}$ & IR, XAS & $\begin{array}{l}\text { Interaction with the support } \\
\text { Favors HPA formation }\end{array}$ & [83] \\
\hline & TEG & $\begin{array}{c}0.7- \\
0.8\end{array}$ & After D & $\mathrm{D} / \mathrm{D}$ & $\mathrm{H}_{2} \mathrm{~S} / \mathrm{H}_{2} / 0.1 \mathrm{MPa} / 673 \mathrm{~K}$ & TEM, XPS, DFT & Additive maximize CoMoS phase content & [87] \\
\hline & TEG & $\begin{array}{c}0.63- \\
0.8\end{array}$ & After D or C & $\mathrm{D}$ or $\mathrm{C} / \mathrm{D}$ & DMDS / $6 \mathrm{MPa} / 673 \mathrm{~K}$ & Raman, UV-visible & $\begin{array}{l}\text { Redissolution/redispersion after TEG } \\
\text { addition. Redistribution of surface entities. } \\
\text { Weaker effect if calcined }\end{array}$ & [84] \\
\hline & DeGbe & 1.33 & I & $\mathrm{D} / \mathrm{D}$ & $\mathrm{H}_{2} \mathrm{~S} / \mathrm{H}_{2} / 0.1 \mathrm{MPa} / 723 \mathrm{~K}$ & $\begin{array}{l}\text { EXAFS during } \\
\text { sulfidation }\end{array}$ & Sulfidation of Mo and Co delayed & [35] \\
\hline & TEG & 2 & I & $\mathrm{D} / \mathrm{D}$ & $\mathrm{H}_{2} \mathrm{~S} / \mathrm{H}_{2} / 0.1 \mathrm{MPa} / 673 \mathrm{~K}$ & $\begin{array}{l}\text { In situ Raman, } \\
\text { XAS, CHNS, } \\
\text { HRTEM } \\
\end{array}$ & Sulfidation of Mo and Co delayed & [85] \\
\hline & TEG & 2 & I & $\mathrm{D} / \mathrm{D}$ & DMDS / 3.5 MPa / $593 \mathrm{~K}$ & $\begin{array}{l}\text { In situ Raman, } \\
\text { XAS, CHNS, } \\
\text { HRTEM } \\
\end{array}$ & Sulfidation of Mo and Co delayed & [85] \\
\hline $\mathrm{NiMoP} / \mathrm{Al}_{2} \mathrm{O}_{3}$ & EG & $\begin{array}{l}1.0- \\
7.0\end{array}$ & I & $\mathrm{D} / \mathrm{D}$ & $\mathrm{H}_{2} \mathrm{~S} / \mathrm{H}_{2} / 0.1 \mathrm{MPa} / 673 \mathrm{~K}$ & $\begin{array}{l}\text { TPR, XPS, HR- } \\
\text { TEM }\end{array}$ & $\begin{array}{l}\text { Decrease of interaction with the support. } \\
\text { Decrease of Mo sulfidation. Increase of } \mathrm{Ni} \\
\text { dispersion and of NiMoS phase formation. }\end{array}$ & [88] \\
\hline $\mathrm{CoMo}(\mathrm{CA}) \mathrm{P}$ & $\begin{array}{l}\text { EG, DEG, } \\
\text { TEG, } \\
\text { glycerol } \\
\end{array}$ & & $\mathrm{I}$ & $\mathrm{D} / \mathrm{D}$ & DMDS / 3.5 MPa / $613 \mathrm{~K}$ & $\begin{array}{l}\text { Raman, TPR, XPS, } \\
\text { HR-TEM }\end{array}$ & $\begin{array}{l}\text { Decrease of the interaction with the support. } \\
\text { Increase of stacking number. }\end{array}$ & [57] \\
\hline NiMo & \multirow{2}{*}{ PEG } & \multirow[t]{2}{*}{0.2} & \multirow{2}{*}{$\mathrm{I}$} & \multirow{2}{*}{$\mathrm{C} / \mathrm{C}$} & \multirow{2}{*}{ DMDS / 5MPa / $523 \mathrm{~K}$} & \multirow{2}{*}{ XPS } & \multirow{2}{*}{ Increase $\mathrm{Ni}$ and Mo dispersion } & \multirow{2}{*}{ [89] } \\
\hline NiMoP & & & & & & & & \\
\hline NiMoP & EG & 1 & I & $\mathrm{D} / \mathrm{D}$ & $\mathrm{H}_{2} \mathrm{~S} / \mathrm{H}_{2} / 0.1 \mathrm{MPa} / 673 \mathrm{~K}$ & TPR, XPS & $\begin{array}{l}\text { Decrease Ni and Mo support interaction } \\
\text { Increase NiMoS phase formation }\end{array}$ & [88] \\
\hline
\end{tabular}

I: during impregnation; SI: successive impregnation; *step before sulfidation of the reference catalyst and of the one prepared with the chelating agent drying (D) / calcination(C) 
Table 8. Effect of non-chelating agent on the activity in HDS and HYD of sulfide catalysts

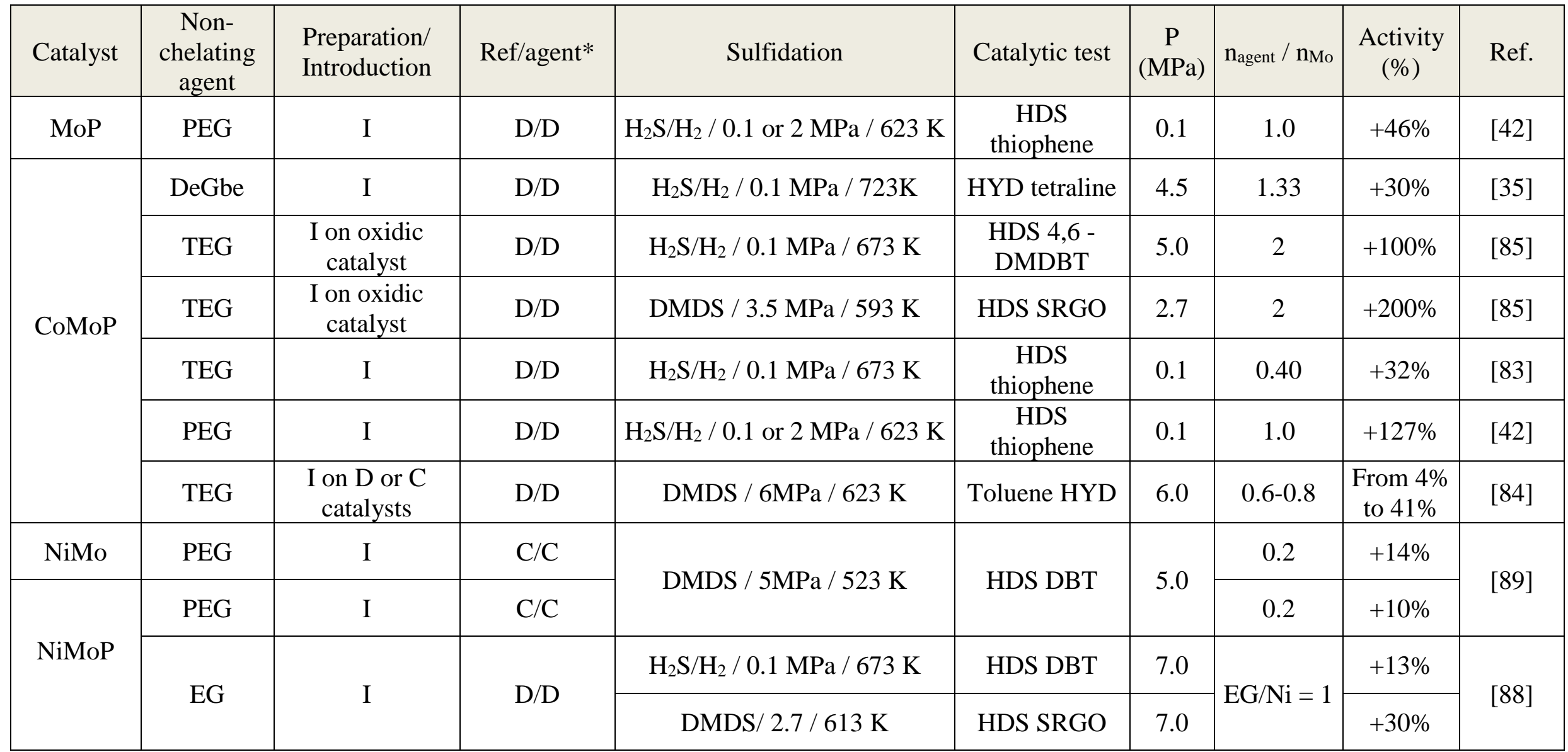

I: during impregnation; *step before sulfidation of the reference catalyst and of the one prepared with the chelating agent drying (D) / calcination(C) 


\subsection{Other types of additives: Bio-inspired molecules}

These are mostly academic studies, not yet advanced to the stage of industrial applications that strive to replace existing additives with cheap, non-toxic and environmentally friendly natural molecules. Natural substances such as saccharose (Fig. 13a) or molecules that can spontaneously polymerize such as dopamine (Fig. 13b) have also been recently investigated.

a)

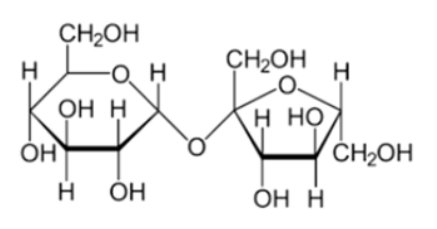

b)

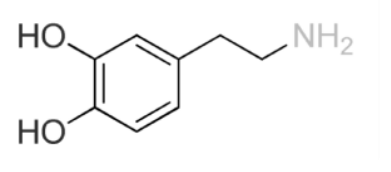

\section{Figure 13. Examples of bio-inspired additives: a) saccharose and b) dopamine}

Saccharose (SA) can be assimilated to a large non-chelating agent, highly soluble, cheap and non-toxic. NiMoP/ $/ \mathrm{Al}_{2} \mathrm{O}_{3}$ doped with saccharose at different stages of preparation and molar ratio $\mathrm{SA} / \mathrm{Ni}=1$ [90] and $\mathrm{SA} / \mathrm{Ni} 0.5,1-3$ [91] demonstrated enhanced catalytic activities. An excessive amount of saccharose is detrimental to HDS activity. Interaction of sugars with alumina surface occurs via sugar hydroxyls and aluminol groups and is affected by the presence of anions [92].

Polydopamine is inspired from the properties of mussel adhesive proteins and was proposed for improving the performances of electrostatic multilayer films [93]. It combines the properties of coating alumina and complexing Mo [94]. The functional groups of dopamine, i.e. the catechol and the amine group are responsible for the strong adhesive properties of the molecule. Moreover, dopamine spontaneously self-polymerizes under ambient conditions, at basic $\mathrm{pH}$. The polymerization is triggered by an oxidation of the molecule in air; no initiator is required. Rajesh et al. evidenced that the presence of polymerized dopamine weakens the interaction with the oxide support (alumina, silica, titania with less effects ) and favors $\mathrm{MoS}_{2}$ crystallites dispersion [95]. It allows enhancing the activity of a $\mathrm{CoMo} / \mathrm{SiO}_{2}$ by a factor of 2 and promotes alumina supported catalysts[96]. 


\section{Conclusion}

Organic additives had a strong impact on the production of industrial HDT catalysts. All catalysts manufactures are now using these additives to provide to refineries efficient catalysts. They are also required now after regeneration in a so-called "rejuvenation" process in order to reach catalytic performances for re-use. The wide diversity of molecules, their impact either on oxidic state or during the activation process has been extensively investigated. Overall, these organic molecules permit to maximize the use of Co and Mo to generate an optimum content of CoMoS phase. If not yet deeply addressed by academy, the use of mixtures of additives, bringing different interactions and probably synergetic effects is a further direction for improving the impact of organic additives. Bio-inspired molecules, by their low toxicity are also of great interest.

\section{Acknowledgments}

The authors thank Eurecat S. A. for fruitful discussions. C. P. thanks the « Pack Ambition Recherche » program of Région Auvergne Rhône-Alpes for a grant. The authors thank Luz Zavala Sanchez for her kind help in the references management.

\section{References}

[1] G. Berrebi, Eur. Patent, 0130650, 1984.

[2] J. van Gestel, J. Leglise, J.C. Duchet, Catalytic properties of a $\mathrm{CoMo} / \mathrm{Al}_{2} \mathrm{O}_{3}$ catalyst presulfided with alkyl polysulfides: Comparison with conventional sulfiding, J. Catal. 145 (1994) 429-436.

[3] P. Dufresne, N. Brahma, F. Labruyere, M. Lacroix, M. Breysse, Activation of off site presulfided Cobalt-Molybdenum catalysts, Catal. Today 29 (1996) 251-254.

[4] F. Labruyere, P. Dufresne, M. Lacroix, M. Breysse, Ex situ sulfidation by alkylpolysulfides: A route for the preparation of highly dispersed supported sulfides, Catal. Today 43 (1998) 111-116.

[5] E. Lyons, Thioglycolic acid as a color test for iron, J. Am. Chem. Soc. 49 (1927) 1916-1920. 
[6] N. Rueda, R. Bacaud, M. Vrinat, Highly Dispersed, Nonsupported Molybdenum Sulfides, J. Catal. 169 (1997) 404-406. doi:10.1006/jcat.1997.1669.

[7] S.P. Kelty, G. Berhault, R. Chianelli, The role of carbon in catalytically stabilized transition metal sulfides, Appl. Catal. A Gen. 322 (2007) 9-15.

[8] J.H. Wilson, G. Berrebi, Sulficat ${ }^{\circledR}$ : Off-Site Presulfiding of Hydroprocessing catalyst From Eurecat, Stud. Surf. Sci. Catal. 38 (1988) 393-398. doi:10.1016/S0167-2991(09)60672-8.

[9] S. Yamada, W.H. Qian, A. Ishihara, G.D. Wang, L. Li, T. Kabe, Methods of activating catalysts for hydrodesulfurization of light gas oil (Part 1) - Catalytic activity of $\mathrm{CoMo} / \mathrm{Al}_{2} \mathrm{O}_{3}$ catalyst presulfided with polysulfides for hydrodesulfurization of dibenzothiophene, J. Japan Pet. Inst. 44 (2001) 217-224.

[10] W.H. Qian, S. Yamada, A. Ishihara, M. Ichinoseki, T. Kabe, Methods of activating catalysts for hydrodesulfurization of light gas oil (Part 2) - Catalytic properties of $\mathrm{CoMo} / \mathrm{Al}_{2} \mathrm{O}_{3}$ presulfided by polysulfides for deep and ultra-deep hydrodesulfurization of light gas oil, J. Japan Pet. Inst. 44 (2001) 225-231.

[11] S. Texier, G. Berhault, G. Perot, V. Harle, F. Diehl, Activation of aluminasupported hydrotreating catalysts by organosulfides: comparison with $\mathrm{H}_{2} \mathrm{~S}$ and effect of different solvents, J. Catal. 223 (2004) 404-418.

[12] R. Rippel, Mercaptoacetic acid and derivatives, Encycl. Ind. Chem. (2012) 555557. doi:10.1002/14356007.a16_265.

[13] M. Saeed, N. Hameed, V. Madan, S. Mansoor, Preparation and Mechanisms studies of Thioglycolic Acid, J. Sci. Ind. Res. (India). 35 (1992) 131-132.

[14] A.M. Cook, K.J. Steel, The stability of thioglycollate solutions. II. Miscellaneous factors associated with the oxidation and stability, J. Pharm. Pharmacol. 11 (1959) 434-441.

[15] N.H. Arakaki, J.G. Espinola, M.G. Fonseca, S. Oliveira, A.N. Sousa, T. Arakaki, Airoldi, Thioglycolic acid grafted onto silica gel and its properties in relation to extracting cations from ethanolic solution determined by calorimetric technique, J. Colloid Interface Sci. 273 (2004) 211-217. 
[16] J.F. Martin, J.T. Spence, Oxidation of thioglycolic acid by molybdenum (V) and molybdenum (VI), J. Phys. Chem. (1970) 3589-3596.

[17] Z. Bugarcic, V. Djordjevic, Kinetics and Mechanism of the Reaction of Platinum (II) Complexes with Thioglycolic Acid, Monatshefte Für Chemie. 129 (1998) $1267-1274$.

[18] E. Michalko, Method of depositing a catalytically active metallic component on a carrier material, US3972829A, 1976.

[19] T. Yasuhito, S. Shigeru, I. Yoshimasa, A catalyst for hydrotreating hydrocarbons and methods of activating the same, 0506206A1, 1988.

[20] N. Frizi, P. Blanchard, E. Payen, P. Baranek, M. Rebeillau, C. Dupuy, J.P. Dath, Genesis of new HDS catalysts through a careful control of the sulfidation of both Co and Mo atoms: Study of their activation under gas phase, Catal. Today 130 (2008) 272-282.

[21] N. Frizi, P. Blanchard, E. Payen, P. Baranek, C. Lancelot, M. Rebeilleau, C. Dupuy, J.P. Dath, Genesis of new gas oil HDS catalysts: Study of their liquid phase sulfidation, Catal. Today 130 (2008) 32-40.

[22] R. Palcheva, L. Kaluza, L. Dimitrov, G. Tyuliev, G. Avdeev, K. Jiratova, A. Spojakina, NiMo Catalysts Supported on the Nb Modified Mesoporous SBA-15 and HMS: Effect of Thioglycolic Acid Addition on HDS, Appl. Catal. A Gen. 520 (2016) 24-34.

[23] J.A. Toledo-Antonio, M.A. Cortes-Jacome, J. Escobar-Aguilar, C. AngelesChavez, J. Navarrete-Bolanos, E. Lopez-Salinas, Upgrading HDS activity of MoS2 catalysts by chelating thioglycolic acid to $\mathrm{MoO}_{\mathrm{x}}$ supported on alumina, Appl. Catal. B-Environmental. 213 (2017) 106-117.

[24] M.S. Thompson, Preparation of high activity silica-supported hydrotreating catalysts and catalysts thus prepared, EP0181035A2, 1985.

[25] E. Yamaguchi, Y. Uragami, H. Yokozuka, K. Uekusa, T. Yamaguchi, S. Abe, T. Kamo, T. Suzuki, Hydrotreatment catalysts for hydrocarbons and methods of preparation, EP0601722A1, 1993. 
[26] Y. Uragami, E. Yamaguchi, H. Yokozuka, K. Uekusa, Hydrotreating catalyst: composition, preparation, and use thereof, WO9641848A1, 1995.

[27] P. Shukis, J. Carruthers, V. Lostagio, High activity catalysts, WO1995031280A1, 1995.

[28] S. Eijsbouts, M. Jansen, Process for sulphiding a hydrotreating catalyst comprising an organic compound comprising N and carbonyl, EP1043069A1, 2000.

[29] S. Eijsbouts, F. Wilhelmus, M. Jansen, T. Kamo, F. Lodewijk, Process for regenerating and rejuvenating additive containing catalysts, WO2001002092A1, 2001.

[30] P. Raybaud, H. Toulhoat, Catalysis by Transition Metal Sulfides: from molecular theory to industrial application, Technip, Paris, France, 2013.

[31] A. Van Veen, J. R., Gerkema, E., Van der Kraan, A. M., \& Knoester, A real support effect on the activity of fully sulphided CoMoS for the hydrodesulphurization of thiophene, J. Chem. Soc., Chem. Comm. 22 (1987) 1684-1686.

[32] Y. Yoshimura, N. Matsubayashi, T. Sato, H. Shimada, A. Nishijima, Molybdate catalysts prepared by a novel impregnation method - Effect of citric acid as a ligand on the catalytic activities, Appl. Catal. 79 (1991) 145-159. doi:10.1016/0926-860x(91)80001-f.

[33] M. Sun, D. Nicosia, R. Prins, The effects of fluorine, phosphate and chelating agents on hydrotreating catalysts and catalysis, Catal. Today 86 (2003) 173-189.

[34] D. Nicosia, R. Prins, The effect of glycol on phosphate-doped $\mathrm{CoMo} / \mathrm{Al}_{2} \mathrm{O}_{3}$ hydrotreating catalysts, J. Catal. 229 (2005) 424-438.

[35] P. Mazoyer, C. Geantet, F. Diehl, C. Pichon, T.S. Nguyen, M. Lacroix, In situ EXAFS study of the sulfidation of a hydrotreating catalyst doped with a non chelating organic additive, Oil Gas Sci. Technol. D Ifp Energies Nouv. 60 (2005) 791-799. doi:10.2516/ogst:2005056.

[36] P. Nesterenko, P. Jones, B. Paull, High performance chelation ion 
chromatography, RSC chromatography monographs, 2011.

[37] N.E. Boland, A.T. Stone, Rates of nickel(II) capture from complexes with NTA, EDDA, and related tetradentate chelating agents by the hexadentate chelating agents EDTA and CDTA: Evidence of a "semijunctive" ligand exchange pathway, Geochim. Cosmochim. Acta 212 (2017) 176-195. doi:10.1016/j.gca.2017.06.003.

[38] X. Solans, M.F. Altaba, J. Garcia-Oricain, Crystal structures of ethylenediaminetetraacetato metal complexes. V. Structures containing the $\left[\mathrm{Fe}\left(\mathrm{C}_{10} \mathrm{H}_{12} \mathrm{~N}_{2} \mathrm{O}_{8}\right)\left(\mathrm{H}_{2} \mathrm{O}\right)\right]^{-}$anion, Acta Crystallogr. Sect. C. 40 (1984) 635-638.

[39] R.A. Mackay, W. Henderson, Introduction to modern inorganic chemistry, CRC Press, 2002.

[40] J.A. Dean, Lange's Handbook of chemistry, 15th ed., McGRAW-HILL, INC., 1972.

[41] K. Bourikas, C. Kordulis, A. Lycourghiotis, The role of the liquid-solid interface in the preparation of supported catalysts, Catal. Rev. Eng. 48 (2006) 363-444. doi:10.1080/01614940600962321.

[42] L. Van Haandel, G.M. Bremmer, E.J.M. Hensen, T. Weber, The effect of organic additives and phosphoric acid on sulfidation and activity of (Co) $\mathrm{Mo}_{2} \mathrm{Al}_{2} \mathrm{O}_{3}$ hydrodesulfurization catalysts, J. Catal. 351 (2017) 95-106. doi:10.1016/j.jcat.2017.04.012.

[43] A.J. van Dillen, R.J.A.M. Terorde, D.J. Lensveld, J.W. Geus, K.P. de Jong, Synthesis of supported catalysts by impregnation and drying using aqueous chelated metal complexes, J. Catal. 216 (2003) 257-264.

[44] J. Chen, F. Mauge, J. El Fallah, L. Oliviero, IR spectroscopy evidence of MoS2 morphology change by citric acid addition on $\mathrm{MoS}_{2} / \mathrm{Al}_{2} \mathrm{O}_{3}$ catalysts - A step forward to differentiate the reactivity of M-edge and S-edge, J. Catal. 320 (2014) $170-179$.

[45] N. Rinaldi, T. Kubota, Y. Okamoto, Effect of citric acid addition on the hydrodesulfurization activity of $\mathrm{MoO}_{3} / \mathrm{Al}_{2} \mathrm{O}_{3}$ catalysts, Appl. Catal. A-General 
374 (2010) 228-236.

[46] E.J.M. Hensen, P.J. Kooyman, Y. van der Meer, A.M. van der Kraan, V.H.J. de Beer, J.A.R. van Veen, R.A. van Santen, The Relation between Morphology and Hydrotreating Activity for Supported $\mathrm{MoS}_{2}$ Particles, J. Catal. 199 (2001) 224235.

[47] T. Shimizu, K. Hiroshima, T. Honma, T. Mochizuki, M. Yamada, Highly active hydrotreatment catalysts prepared with chelating agents, Catal. Today 45 (1998) 271-276. doi:10.1016/S0920-5861(98)00227-2.

[48] K. Inamura, K. Uchikawa, S. Matsuda, Y. Akai, Preparation of active HDS catalysts by controlling the dispersion of active species, Appl. Surf. Sci. 121-122 (1997) 468-475.

[49] M.A. Lélias, P.J. Kooyman, L. Mariey, L. Oliviero, A. Travert, J. Van Gestel, J.A.R. Van Veen, F. Maugé, Effect of NTA addition on the structure and activity of the active phase of cobalt-molybdenum sulfide hydrotreating catalysts, (2009). doi:10.1016/j.jcat.2009.07.006.

[50] M.A. Lélias, E. Le Guludec, L. Mariey, J. Van Gestel, A. Travert, L. Oliviero, F. Maugé, Effect of EDTA addition on the structure and activity of the active phase of cobalt-molybdenum sulfide hydrotreatment catalysts, Catal. Today. 150 (2010) 179-185. doi:10.1016/j.cattod.2009.07.107.

[51] M.S. Rana, J. Ramirez, A. Gutierrez-Alejandre, J. Ancheyta, L. Cedeno, S.K. Maity, Support effects in CoMo hydrodesulfurization catalysts prepared with EDTA as a chelating agent, J. Catal. 246 (2007) 100-108. doi:10.1016/j.jcat.2006.11.025.

[52] P. Mazoyer, C. Geantet, F. Diehl, S. Loridant, M. Lacroix, Role of chelating agent on the oxidic state of hydrotreating catalysts, Catal. Today 130 (2008) 75-79.

[53] L. Coulier, V.H.J. de Beer, J.A.R. van Veen, J.W. Niemantsverdriet, On the formation of cobalt-molybdenum sulfides in silica-supported hydrotreating model catalysts, Top. Catal. 13 (2000) 99-108. doi:10.1023/a:1009037006529.

[54] T. Huang, J. Xu, Y. Fan, Effects of concentration and microstructure of active 
phases on the selective hydrodesulfurization performance of sulfided $\mathrm{CoMo} / \mathrm{Al}_{2} \mathrm{O}_{3}$ catalysts, Appl. Catal. B-Environmental 220 (2018) 42-56. doi:10.1016/j.apcatb.2017.08.029.

[55] L. Peña, D. Valencia, T. Klimova, CoMo/SBA-15 catalysts prepared with EDTA and citric acid and their performance in hydrodesulfurization of dibenzothiophene, Appl. Catal. B Environ. 147 (2014) 879-887. doi:10.1016/j.apcatb.2013.10.019.

[56] S.L. González-Cortés, Y. Qian, H.A. Almegren, T. Xiao, V.L. Kuznetsov, P.P. Edwards, Citric acid-assisted synthesis of $\gamma$-alumina-supported high loading CoMo sulfide catalysts for the hydrodesulfurization (HDS) and hydrodenitrogenation (HDN) reactions, Appl. Petrochemical Res. 5 (2015) 181197. doi:10.1007/s13203-015-0097-y.

[57] A. Pimerzin, A. Mozhaev, A. Varakin, K. Maslakov, P. Nikulshin, Comparison of citric acid and glycol effects on the state of active phase species and catalytic properties of $\mathrm{CoPMo} / \mathrm{Al}_{2} \mathrm{O}_{3}$ hydrotreating catalysts, Appl. Catal. BEnvironmental 205 (2017) 93-103. doi:10.1016/j.apcatb.2016.12.022.

[58] Y. Zhang, W. Han, X. Long, H. Nie, Redispersion effects of citric acid on $\mathrm{CoMo} / \gamma-\mathrm{Al}_{2} \mathrm{O}_{3}$ hydrodesulfurization catalysts, Catal. Commun. 82 (2016) 20-23.

[59] K. Kobayashi, M. Nagai, Active sites of sulfided NiMo/Al2O3 catalysts for 4,6dimethyldibenzothiophene hydrodesulfurization-effects of $\mathrm{Ni}$ and $\mathrm{Mo}$ components, sulfidation, citric acid and phosphate addition, Catal. Today 292 (2017) 74-83. doi:10.1016/j.cattod.2017.01.040.

[60] J. Escobar, M.C. Barrera, A.W. Gutierrez, J.E. Terrazas, Benzothiophene hydrodesulfurization over NiMo/alumina catalysts modified by citric acid. Effect of addition stage of organic modifier, Fuel Process. Technol. 156 (2017) 33-42.

[61] V.A. Suárez-Toriello, C.E. Santolalla-Vargas, J.A. De Los Reyes, A. VázquezZavala, M. Vrinat, C. Geantet, Influence of the solution $\mathrm{pH}$ in impregnation with citric acid and activity of $\mathrm{Ni} / \mathrm{W} / \mathrm{Al}_{2} \mathrm{O}_{3}$ catalysts, "Journal Mol. Catal. A, Chem. 404-405 (2015) 36-46. doi:10.1016/j.molcata.2015.04.005. 
[62] H. Li, M. Li, Y. Chu, F. Liu, H. Nie, Essential role of citric acid in preparation of efficient $\mathrm{NiW} / \mathrm{Al}_{2} \mathrm{O}_{3}$ HDS catalysts, Appl. Catal. A Gen. 403 (2011) 75-82. doi:10.1016/j.apcata.2011.06.015.

[63] M.A. Lelias, J. van Gestel, F. Mauge, J.A.R. van Veen, Effect of NTA addition on the formation, structure and activity of the active phase of cobalt-molybdenum sulfide hydrotreating catalysts, Catal. Today 130 (2008) 109-116.

[64] A.M. de Jong, V.H.J. de Beer, J.A.R. van Veen, J.W. Niemantsverdriet, Surface Science Model of a Working Cobalt-Promoted Molybdenum Sulfide Hydrodesulfurization Catalyst: Characterization and Reactivity, J. Phys. Chem. 100 (1996) 17722-17724.

[65] Y. Ohta, T. Shimizu, T. Honma, M. Yamada, Effect of chelating agents on HDS and aromatic hydrogenation over CoMo- and $\mathrm{NiW} / \mathrm{Al}_{2} \mathrm{O}_{3}$, Stud. Surf. Sci. Catal. 127 (1999) 161-168.

[66] T. Fujikawa, H. Kimura, K. Kiriyama, K. Hagiwara, Development of ultra-deep HDS catalyst for production of clean diesel fuels, Catal. Today 111 (2006) 188193.

[67] J.A. Bergwerff, T. Visser, B.R.G. Leliveld, B.D. Rossenaar, K.P. de Jong, B.M. Weckhuysen, Envisaging the physicochemical processes during the preparation of supported catalysts: Raman microscopy on the impregnation of $\mathrm{Mo}$ onto $\mathrm{Al}_{2} \mathrm{O}_{3}$ extrudates, J. Am. Chem. Soc. 126 (2004) 14548-14556. doi:10.1021/ja040107c.

[68] J.A.R. van Veen, H.A. Colijn, P.A.J.M. Hendriks, A.J. van Welsenes, On the formation of type I and type II NiMoS phases in $\mathrm{NiMo} / \mathrm{Al}_{2} \mathrm{O}_{3}$ hydrotreating catalysts and its catalytic implications, Fuel Process. Technol. 35 (1993) 137157.

[69] R. Cattaneo, T. Shido, R. Prins, The Relationship between the Structure of $\mathrm{NiMo} / \mathrm{SiO}_{2}$ Catalyst Precursors Prepared in the Presence of Chelating Ligands and the Hydrodesulfurization Activity of the Final Sulfided Catalysts, J. Catal. 185 (1999) 199-212.

[70] R. Cattaneo, T. Shido, R. Prins, A XANES temperature-programmed 
sulphidation study of modified $\mathrm{NiMo} / \mathrm{SiO}_{2}$ hydrotreating catalysts, Stud. Surf. Sci. Catal. 127 (1999) 421-425.

[71] L. Medici, R. Prins, The Influence of Chelating Ligands on the Sulfidation of Ni and $\mathrm{Mo}$ in $\mathrm{NiMo} / \mathrm{SiO}_{2}$ Hydrotreating Catalysts, J. Catal. 163 (1996) 38-49.

[72] L. Medici, R. Prins, Structure of Oxidic $\mathrm{NiMo} / \mathrm{SiO}_{2}$ Hydrotreating Catalyst Precursors, J. Catal. 163 (1996) 28-37.

[73] R. Cattaneo, F. Rota, R. Prins, An XAFS Study of the Different Influence of Chelating Ligands on the HDN and HDS of [gamma]- $\mathrm{Al}_{2} \mathrm{O}_{3}$-Supported NiMo Catalysts, J. Catal. 199 (2001) 318-327.

[74] G. Kishan, L. Coulier, V.H.J. de Beer, J.A.R. van Veen, J.W. Niemantsverdriet, Sulfidation and thiophene hydrodesulfurization activity of nickel tungsten sulfide model catalysts, prepared without and with chelating agents, J. Catal. 196 (2000) 180-189. doi:10.1006/jcat.2000.3013.

[75] G. Kishan, L. Coulier, V.H.J. De Beer, J.A.R. van Veen, J.W. Niemantsverdriet, Preparation of highly active NiW hydrotreating model catalysts with 1,2cyclohexanediamine-N,N,NANA-tetraacetic acid (CyDTA) as a chelating agent, Chem. Commun.. (2000) 1103-1104.

[76] G. Kishan, L. Coulier, J.A.R. van Veen, J.W. Niemantsverdriet, Promoting synergy in CoW sulfide hydrotreating catalysts by chelating agents, J. Catal. 200 (2001) 194-196. doi:10.1006/jcat.2001.3203.

[77] P. Blanchard, C. Mauchausse, E. Payen, J. Grimblot, O. Poulet, N. Boisdron, R. Loutaty, Preparation and characterization of $\mathrm{CoMo} / \mathrm{Al}_{2} \mathrm{O}_{3} \mathrm{HDS}$ catalysts: Effects of a complexing agent, Stud. Surf. Sci. Catal. 91 (1995) 1037-1049.

[78] Roles d'additifs organiques sur des catalyseurs d'hydrotraitement, Université Claude Bernard - Lyon 1, 2003.

[79] O. V. Klimov, A. V. Pashigreva, G.A. Bukhtiyarova, S. V. Budukva, M.A. Fedotov, D.I. Kochubey, Y.A. Chesalov, V.I. Zaikovskii, A.S. Noskov, Bimetallic Co-Mo complexes: A starting material for high active hydrodesulfurization catalysts, Catal. Today 150 (2010) 196-206. 
[80] B. Ngoc-Quynh, C. Geantet, G. Berhault, Maleic acid, an efficient additive for the activation of regenerated $\mathrm{CoMo} / \mathrm{Al}_{2} \mathrm{O}_{3}$ hydrotreating catalysts, J. Catal. 330 (2015) 374-386.

[81] J. Chen, J. Mi, K. Li, X. Wang, E.D. Garcia, Y. Cao, L. Jiang, L. Oliviero, F. Mauge, Role of Citric Acid in Preparing Highly Active $\mathrm{CoMo} / \mathrm{Al}_{2} \mathrm{O}_{3}$ Catalyst: From Aqueous Impregnation Solution to Active Site Formation, Ind. Eng. Chem. Res. 56 (2017) 14172-14181. doi:10.1021/acs.iecr.7b02877.

[82] K.A. Leonova, O. V. Klimov, D.I. Kochubey, Y.A. Chesalov, E.Y. Gerasimov, I.P. Prosvirin, A.S. Noskov, Optimal pretreatment conditions for Co-Mo hydrotreatment catalysts prepared using ethylenediamine as a chelating agent, Catal. Today 220-222 (2014) 327-336.

[83] D. Nicosia, R. Prins, The effect of phosphate and glycol on the sulfidation mechanism of $\mathrm{CoMo} / \mathrm{Al}_{2} \mathrm{O}_{3}$ hydrotreating catalysts: an in situ QEXAFS study, J. Catal. 231 (2005) 259-268.

[84] V. Costa, K. Marchand, M. Digne, C. Geantet, New insights into the role of glycol-based additives in the improvement of hydrotreatment catalyst performances, Catal. Today 130 (2008) 69-74.

[85] T.S. Nguyen, S. Loridant, C. Lorentz, T. Cholley, C. Geantet, Effect of Glycol on the Formation of Active Species and Sulfidation Mechanism of $\mathrm{CoMoP} / \mathrm{Al}_{2} \mathrm{O}_{3}$, Appl. Catal. B Environ. 107 (2011) 59-67.

[86] V. Costa, Compréhension du rôle des additifs du type glycol sur l'amélioration des performances des catalyseurs d'hydrotraitement, Université de Lyon 1, 2008.

[87] V. Costa, B. Guichard, M. Digne, C. Legens, P. Lecour, K. Marchand, P. Raybaud, E. Krebs, C. Geantet, A rational interpretation of improved catalytic performances of additive-impregnated dried CoMo hydrotreating catalysts: a combined theoretical and experimental study, Catal. Sci. Technol. 3 (2013) 140151.

[88] J. Escobar, M.C. Barrera, J.A. Toledo, M.A. Cortes-Jacome, C. Angeles-Chavez, S. Nunez, V. Santes, E. Gomez, L. Diaz, E. Romero, J.G. Pacheco, Effect of 
ethyleneglycol addition on the properties of $\mathrm{P}$-doped $\mathrm{NiMo} / \mathrm{Al}_{2} \mathrm{O}_{3} \mathrm{HDS}$ Catalysts: part I. Materials preparation and characterization, Appl. Catal. B Environ. 88 (2009) 564-575.

[89] R. Iwamoto, N. Kagami, Y. Sakoda, A. Iino, Effect of Polyethylene Glycol Addition on $\mathrm{NiO}-\mathrm{MoO}_{3} / \mathrm{Al}_{2} \mathrm{O}_{3}$ and $\mathrm{NiO}-\mathrm{MoO}_{3}-\mathrm{P}_{2} \mathrm{O}_{5} / \mathrm{Al}_{2} \mathrm{O}_{3}$ Hydrodesulfurization Catalyst, J. Japan Pet. Inst. 48 (2005) 351-357. doi:10.1627/jpi.48.351.

[90] J. Escobar, A.W. Gutierrez, M.C. Barrera, J.A. Colin, NiMo/alumina hydrodesulphurization catalyst modified by saccharose: Effect of addition stage of organic modifier, Can. J. Chem. Eng. 94 (2016) 66-74.

[91] J. Escobar, M.C. Barrera, A.W. Gutierrez, M.A. Cortes-Jacome, C. AngelesChavez, J.A. Toledo, D.A. Solis-Casados, Highly active P-doped sulfided NiMo/alumina HDS catalysts from Mo-blue by using saccharose as reducing agents precursor, Appl. Catal. B Environ. 237 (2018) 708-720.

[92] K. Singh, S. Mohan, Kinetic studies of the sucrose adsorption onto an alumina interface, Appl. Surf. Sci. 221 (2011) 308-318.

[93] J.J. Wu, L. Zhang, Y. Wang, Y.H. Long, H. Gao, X.L. Zhang, N. Zhao, Y.L. Cai, J. Xu, Mussel-inspired chemistry for robust and surface-modifiable multilayer films, Langmuir 27 (2011) 13684-13691.

[94] C.Y. Zhao, J.H. Kong, L.P. Yang, X.Y. Yao, S.L. Phua, X.H. Lua, The dopamine-Mo VI complexation-assisted large-scale aqueous synthesis of a single-layer $\mathrm{MoS}_{2} /$ carbon sandwich structure for ultrafast, long-life lithium-ion batteries, Chem. Commun. 50 (2014) 9672-9675. doi:10.1039/C4CC04099F.

[95] R. Munirathiam, D. Laurenti, G.D. Pirngruber, D. Uzio, Efficient CoMoS catalysts supported on bio-inspired polymer coated alumina for hydrotreating reactions, Chemistryselect. 2 (2017) 2373-2382.

[96] D. Laurenti, R. Munirathiam, G.D. Pirngruber, D. Uzio, Catecholamine-based catalyst and use thereof in a hydroprocessing and/or hydrocracking method, WO2017167522A1, 2017. 